THE ECB FINANCIAL

ACCOUNTS AND

\title{
ECB FINANCIAL
}

\section{STRENGTH OVER}

\section{THE FIRST II YEARS}

by Olivier Vergote, Werner Studener, loannis Efthymiadis and Niall Merriman 


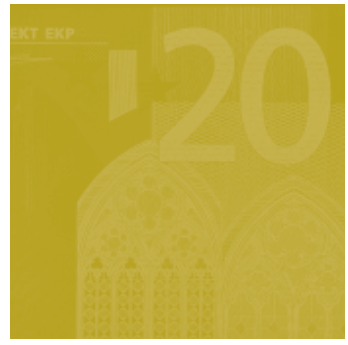

\section{OCCASIONAL PAPER SERIES}

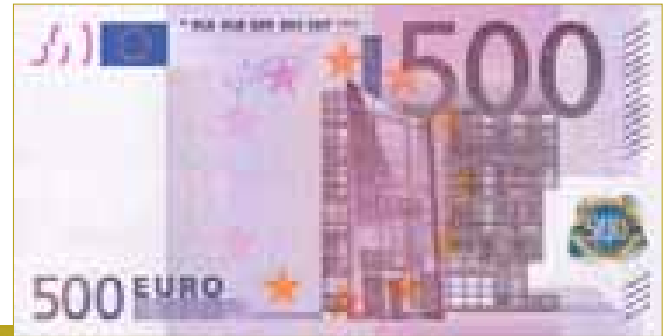

In 2010 all ECB publication eature a motif taken from the $€ 500$ banknote.

\author{
MAIN DRIVERS OF THE ECB \\ FINANCIAL ACCOUNTS \\ AND ECB FINANCIAL STRENGTH \\ OVER THE FIRST II YEARS '
}

by Olivier Vergote, Werner Studener, loannis Efthymiadis and Niall Merriman

NOTE: This Occasional Paper should not be reported as representing the views of the European Central Bank (ECB).

The views expressed are those of the authors and do not necessarily reflect those of the $E C B$. 
(c) European Central Bank, 2010

\section{Address}

Kaiserstrasse 29

60311 Frankfurt am Main, Germany

Postal address

Postfach 160319

60066 Frankfurt am Main, Germany

Telephone

+496913440

Internet

http://www.ecb.europa.eu

Fax

+496913446000

All rights reserved.

Any reproduction, publication and reprint in the form of a different publication, whether printed or produced electronically, in whole or in part, is permitted only with the explicit written authorisation of the ECB or the authors.

Information on all of the papers published in the ECB Occasional Paper Series can be found on the ECB's website. http://www.ecb.europa.eu/pub/scientific/ ops/date/html/index.en.html

ISSN 1607-1484 (print)

ISSN 1725-6534 (online) 


\section{CONTENTS}

ABSTRACT

SUMMARY

I INTRODUCTION

2 MAIN DRIVERS OF ECB BALANCE SHEET ITEMS

2.1 Financial market developments and management of foreign reserves ? 2.1.1 Foreign reserve holdings 2.1.2 Own funds portfolio

2.2 Liquidity-providing operations in foreign currency during the financial crisis

2.2.1 Liquidity operations in foreign currency and provision of euro to other central banks

2.2.2 Impact on the balance sheet

2.3 ECB banknote issuance

3 MAIN DRIVERS OF ECB PROFIT AND LOSS

3.1 Main income and expense drivers

3.1.1 Seigniorage as a function of banknote demand and the monetary policy stance

3.1.2 Financial market developments and reserve management

3.1.3 Impact of the 2007-09

financial crisis on ECB

financial returns

3.2 Financial buffers

3.2.1 Revaluation accounts

3.2.2 Reserve and provision

3.2.3 Paid-up capital

\section{9}

9

15

4 FINANCIAL STRENGTH

4.1 Why does the ECB need financial strength?

4.1.1 Independence

4.1.2 Price stability

4.1.3 Financial stability

4.2 ECB financial strength

4.2.1 Legislative provisions

4.2.2 Financial buffers

4.2.3 Policy objective and seigniorage

4.3 Risks to the financial position of the ECB

4.3.1 Banknote demand and disinflation

4.3.2 Financial market developments

4.3.3 Financial instability

5 CONCLUSIONS

APPENDIX

REFERENCES

EUROPEAN CENTRAL BANK OCCASIONAL PAPER SERIES SINCE 2008

3.2.4 History of setting up and using financial buffers 


\section{ABSTRACT}

This paper analyses the main drivers of the ECB's balance sheet and profit and loss account over the first 11 years of the ECB's existence. Furthermore, the paper assesses the financial strength of the ECB. As monetary policy operations are normally conducted by national central banks under the impulse and instructions from the ECB, the Eurosystem balance sheet is the primary reference for the analysis of Eurosystem monetary policy operations.

Three main drivers of the balance sheet and profit and loss account are identified. Firstly, financial market developments and portfolio management decisions imply changes in the value of the foreign reserve and own funds portfolios, which represent a substantial part of the balance sheet (with the share of own funds becoming increasingly larger over the period under review). At the same time, the profit and loss account depends to an important degree on interest income and expenses, realised gains and losses, and write-downs on these portfolios. Secondly, strong banknote demand has gradually increased the size of the balance sheet since the euro changeover in 2002. Banknotes in circulation also provide a strong base for seigniorage income, which is an important item of the profit and loss account. Thirdly, the liquidity-providing operations in foreign currency, which the Eurosystem has undertaken since 2007 in response to the financial crisis, increased significantly the size of the ECB's (and the Eurosystem's) balance sheet. In terms of income and expenses, these operations were rather immaterial at the level of the ECB, although the income generated was substantial at the Eurosystem level.

The ECB has remained financially strong over the 11-year period. Factors that support the financial position are strong legislative provisions on e.g. independence and income, the use of financial buffers, seigniorage as a reliable income source and an effective loss-coverage mechanism. The main risk stems from adverse financial market developments, in particular low interest rates and depreciating foreign reserve currencies, implying security price and currency write-downs.

Key words: central banking, central bank balance sheet, financial accounts, financial strength

JEL classification: E58, E42, M41 


\section{SUMMARY}

This paper identifies and analyses the main drivers of the ECB's balance sheet and profit and loss account over the first 11 years of ECB existence. Furthermore, the financial strength of the ECB is assessed. As monetary policy operations are normally conducted by national central banks under the impulse and instructions from the ECB, the Eurosystem balance sheet is the primary reference for the analysis of Eurosystem monetary policy operations.

Three main drivers have been identified for the balance sheet developments and profit/loss: financial market developments and portfolio management, the special operations implemented during the financial crisis, and banknote issuance. The following findings were made concerning their impact on the balance sheet items:

- Financial market developments and portfolio management decisions led to significant changes in the value of foreign currency assets and euro-denominated assets. For foreign currency assets, a decomposition of the changes into volume and exchange rate effects has been made. Prominent volume effects were the EUR/USD exchange rate intervention in 2000, gold sales during 2005-09, and the gradual rebalancing in favour of the Japanese yen portfolio. Important exchange rate effects resulted from the long period of US dollar and Japanese yen depreciation, the strong rise in the gold price since 2005, and the strong Japanese yen appreciation in 2008 . These developments also offset each other occasionally, e.g. the strong increase in the gold price helped to offset the depreciation of the US dollar portfolio (in EUR terms) in the second half of the 11-year period.

Valuation gains are prudently recorded in revaluation accounts in accordance with the ESCB/Eurosystem accounting rules, preventing potentially temporary unrealised gains arising from favourable exchange rate developments are taken as income (and distributed). The use of revaluation accounts proved useful, as certain revaluations were indeed temporary, in particular for the US dollar holdings.

The size of the ECB's own funds portfolio, which is invested in euro-denominated assets and is thus not subject to exchange rate risk, increased strongly over time due mainly to inflows from the investment of the ECB risk provision into the own funds, but also from the reinvestment of the income generated over the years.

- The liquidity-providing operations in foreign currency, which the ECB has undertaken since 2007 as a response to the financial crisis, tripled the size of the ECB balance sheet by end-2008 and gradually faded out in 2009. The increase relates mainly to the euro leg of USD-EUR operations in which the ECB intermediated between the Federal Reserve and the Eurosystem national central banks (NCBs). The NCBs provided dollars to Eurosystem monetary policy counterparties as part of the Eurosystem's liquidity-providing operations. On the asset side, the settlement of the transactions with the NCBs increased the ECB's "other claims within the Eurosystem (net)" by about $€ 217$ billion. On the liabilities side, the euro part of the swap transactions with the Federal Reserve did not settle, but remained "liabilities to non-euro area residents denominated in euro". The size of the operations with other central banks was much smaller and totalled on average $€ 34$ billion in late 2008 .

- The ECB banknote issuance has increased the ECB balance sheet gradually over time since 2002. Strong demand for euro banknotes boosted the total euro banknote issuance (tripling the stock over the period 2002-09), of which $8 \%$ is assigned to the ECB. 
The following findings were made concerning the impact of three (actual and potential) drivers on the profit and loss account items:

- Seigniorage income proved to be a reliable income source in the long run. Seigniorage contributed increasingly to ECB interest income, reaching $€ 2,230$ million in 2008 , some $84 \%$ of the surplus before any transfer to the risk provision. However, seigniorage income significantly depends on the level of the interest rate on the main refinancing operations (marginal MRO rate) and fell markedly to $€ 787$ million in 2009.

- Financial market developments and portfolio management had an important impact on the financial result through three channels. First, write-downs due to exchange rate developments, which were strong in 2003-04 and 2007, ranging between $€ 2$ billion and $€ 4$ billion. Second, realised gains, which were occasionally significant due to the exchange rate intervention in 2000 ( $€ 2.5$ billion), and gold sales between 2005 and 2009. Third, net interest income (excluding seigniorage income), which depends on the interest rate gap between mainly the US interest rates and the euro area marginal MRO rate.

- The liquidity-providing operations in foreign currency are a factor that in principle could have an impact on the financial result, but the actual impact has been minor for the ECB up to the end of 2009.

- The financial crisis in general brought favourable revaluation developments reflecting the fact that ECB portfolios are mostly invested in high-quality fixed-income instruments and exchange rate developments were overall favourable, but seigniorage dropped due to lower interest rates.
The assessment of the ECB's financial strength led to the following conclusions:

- The ECB remained financially strong throughout the 11-year period. The ECB pursues financial strength to be able to credibly commit to its price stability objective and credibly perform other potentially costly tasks relating to its general mandate. Strong legislative provisions providing financial independence and transparency on ECB income acted as a strong base to protect the financial position. Furthermore, the financial buffers sufficed for the purpose of absorbing a financial loss, thereby protecting paid-up capital, except in 2004 when a loss of $€ 1.3$ billion was offset against Eurosystem monetary income. Financial losses were offset mainly through the risk provision, partly because it can be built up faster than the general reserve mechanism. In addition, the financial result was increasingly supported by seigniorage income, whilst the ESCB accounting rules, particularly the principle of prudence, also prevented the ECB from incurring even greater losses in periods of depreciating currencies through the use of revaluation accounts for recording unrealised gains.

- Although the financial position of the ECB remained strong, the 11-year experience has pointed out some risks. Financial market developments have posed the biggest threat mainly through exchange rate risk, which resulted in significant write-downs at times. This exposure is likely to test the financial buffers again in the future. Furthermore, seigniorage became an important factor, but would be significantly lower in the near future despite strong banknote demand if the level of the marginal MRO rate were to remain low. 
I

\section{INTRODUCTION}

Since the European Central Bank (ECB) was founded on 1 June 1998 and the euro was launched in January 1999, the ECB and the Eurosystem have faced some daunting challenges. In particular, as a new institution, the ECB had to gain credibility and win the confidence of the public and the financial markets that it would maintain price stability. The Protocol on the Statute of the European System of Central Banks (ESCB) and of the European Central Bank provided the ECB with financial means: capital, foreign reserve assets, monetary income as a means of covering financial losses and explicit profit distribution rules with the possibility to build up a general reserve fund. These legislative provisions aimed to support the ECB in performing its tasks, in particular conducting monetary policy. Profit generation is not the main aim, and also the balance sheet structure and profit and loss account items are quite different from those of private financial institutions.

A number of factors affected the financial situation of the ECB through the years. Moreover, there was an awareness that the successful execution of its tasks may depend on solid financial resources. Over the years, the ECB grew as an institution, both in size and reputation. It developed new activities and saw new EU Member States adopting the euro. On its balance sheet, the ECB held foreign reserves of which the financial market exposure could weigh materially on the financial result through write-downs. The transfer of the foreign reserves from the Eurosystem national central banks (NCBs) generated a remunerated, EUR-denominated claim of the NCBs on the ECB. Therefore, this transfer resulted in the ECB being exposed to the interest rate gap between the interest earned on investments (mainly in USD) and the interest paid on the foreign reserves to the NCBs (in EUR). Since 2002, the ECB interest income was further supported by seigniorage, i.e. the interest income arising from the allocation of euro banknotes within the Eurosystem. However, with a young currency such as the euro, the future path of the banknote component of seigniorage was unclear initially. Starting in mid-2007, in a period of financial crisis, the Eurosystem undertook foreign currency liquidity-providing operations and also lent euro to other central banks. Reflecting the internal allocation of tasks within the Eurosystem, the ECB engaged in a number of transactions related to these exceptional operations, which affected its balance sheet.

This paper analyses the main drivers of the ECB financial accounts over the first 11 years up to December 2009. In particular, the main drivers of the ECB balance sheet items and of ECB profit and loss are analysed. Furthermore, the financial buffers and their smoothing function are presented. Finally, the need for financial strength is discussed and the financial strength of the ECB is assessed. In this last part, the paper takes a step back from the financial accounts and discusses the macroeconomic relevance of central bank financial accounts, in particular in the context of the ECB and the Eurosystem.

Three drivers of the ECB balance sheet are analysed. Firstly, the effect of financial market developments on the foreign reserve holdings is analysed. Secondly, the impact of the special liquidity operations (in foreign currency and in euro) in which the ECB participated during the 2007-09 financial crisis is studied. Thirdly, the ECB banknote issuance is discussed.

Three drivers of ECB income and expenditures are examined. First, the dynamics of seigniorage income are analysed. Second, the impact of financial market developments on the financial result is pointed out. Third, a check is made for the effects of the financial crisis on the profit and loss account.

The ECB's financial strength is assessed starting from the definition of Stella (2008) where financial strength is used to describe "the extent to which an entity is constrained by its financial situation in pursuing its strategic goals or policies. An entity is financially strong 
when it is relatively unconstrained and weak when financial constraints are binding on policy choices." Before assessing the ECB's financial strength, the case for financial strength in the context of a central bank is summarised based on results in the literature. Next, a number of components of ECB financial strength are presented. Finally, the risks to a central bank's financial strength are listed and related to the ECB experience.

Section 2 analyses the main drivers of ECB balance sheet items. Section 3 analyses the main drivers of ECB profit and loss. Section 4 discusses the ECB's financial strength. 
2

\section{MAIN DRIVERS OF ECB BALANCE SHEET} ITEMS

This section presents three main drivers of ECB balance sheet developments. First, financial market developments and portfolio management decisions were an important factor, which led to changes in the composition and values of the foreign reserve and own funds portfolios. The foreign reserve portfolio developments are analysed making a distinction between exchange rate and volume effects. Furthermore, the use of revaluation accounts in handling changes in market valuation is explained. The liquidity operations in which the ECB intermediated to provide foreign currency to Eurosystem counterparties and euro to other central banks were a second driver. A closer look is taken at the increase in the level of the balance sheet that took place at the end of 2008. A third driver was ECB banknote issuance, which has increased strongly over time and expanded the balance sheet gradually. An overview of the annual balance sheet during the period 1998-2009 is given in the Appendix.

\section{I FINANCIAL MARKET DEVELOPMENTS AND MANAGEMENT OF FOREIGN RESERVES}

The foreign reserve holdings of the ECB comprise gold and net assets in foreign currency, which are items of considerable size on the balance sheet. One important reason is the decentralised set-up of the Eurosystem's monetary policy implementation, which leaves the monetary policy operations on the NCB balance sheets only. The foreign reserve holdings enable the ECB to conduct foreign exchange operations, which is one of its basic tasks. The size of these holdings is affected by interventions on the foreign exchange market and decisions relating to the ECB foreign reserve management. The value depends on asset price movements. The euro equivalent of the foreign reserve holdings depends on exchange rate developments for the underlying assets.

The ECB also manages its own funds, i.e. its paid-up capital and reserves. The own funds are invested in euro-denominated assets and the value of that portfolio also depends on asset price movements. First, the ECB foreign reserves are analysed. Second, the developments in the own funds are discussed.

\section{I.I FOREIGN RESERVE HOLDINGS}

The foreign reserve holdings of the Eurosystem central banks are significant compared with other central banks. The share of foreign reserves represented $66 \%$ of ECB total assets in 1999 , down to $35 \%$ by 2006 as other items grew; in particular, banknotes were added to the total in 2002 and grew strongly thereafter.

Chart 1 shows how the total euro equivalent varied between $€ 35$ billion and $€ 50$ billion

\section{Chart I US dollar, Japanese yen and gold portfolio in euro equivalent}

(left panel, EUR billions; right panel, percentages)

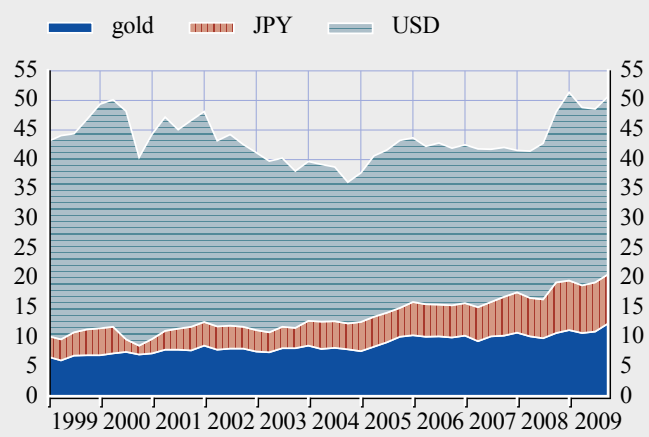

Source: ECB.

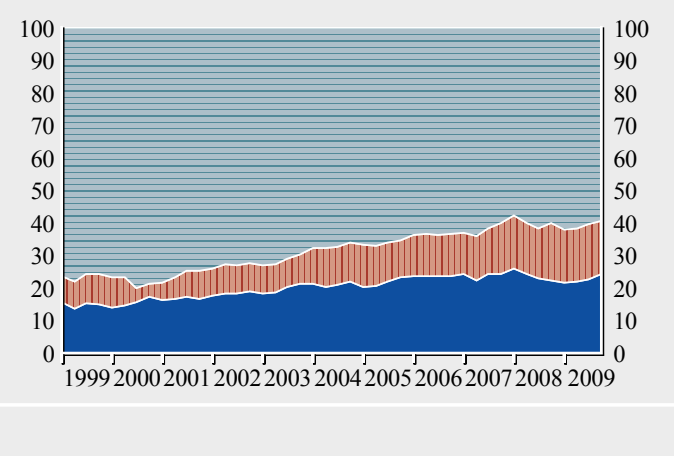


and how changes in the underlying assets caused these movements. At the start, $15 \%$ of the holdings were in gold and the remaining part was composed of $90 \%$ in US dollars and $10 \%$ in Japanese yen. Charts 2 to 4 present the developments in the US dollar, Japanese yen and gold holdings, respectively. Each chart has four panels showing the foreign reserve volume, the exchange rate, the euro equivalent of the holdings and a decomposition of the changes in the euro equivalent into volume and exchange rate and gold price (hereafter "price") components. The decomposition is explained in the Appendix.

Firstly, the volume effects are discussed. Secondly, the exchange rate and gold price developments are summarised and then the joint effects are discussed.

\section{VOLUME DEVELOPMENTS}

At the beginning of 1999, the ECB foreign reserves consisted of about USD 35 billion, JPY 445 billion and 24 million ounces of gold. The amounts changed somewhat when the capital key, which determines the contribution of each ESCB member, changed or an EU Member State adopted the euro. However, these structural breaks were small and there are a number of more important reasons why the volume of reserves changed.

\section{Intervention}

The main reason why central banks keep foreign exchange reserves is for potential interventions on the currency markets, usually to support their own currency. The ECB intervened in the foreign exchange market in the autumn of 2000.

\section{Chart 2 US dollar holdings}

(a) Volume (USD bn)

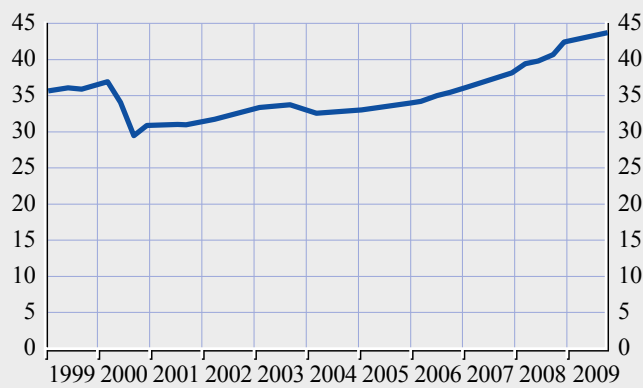

(c) Euro equivalent (bn)

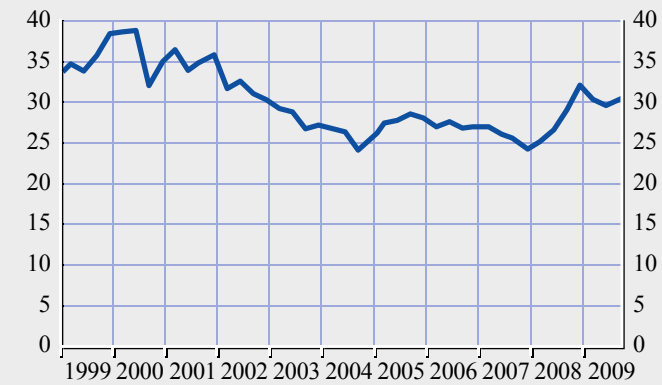

Source: ECB. (b) Exchange rate EUR/USD

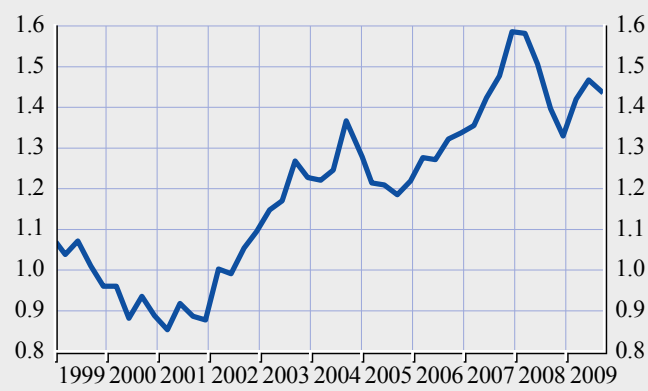

(d) Exchange rate and volume components (EUR bn)

price effect

เіпі! volume effect

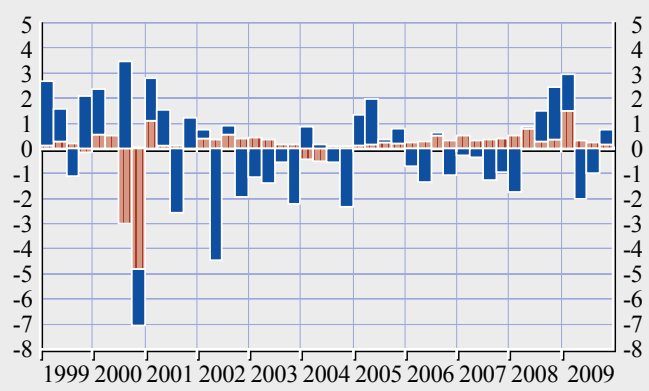


(a) Volume (JPY bn)

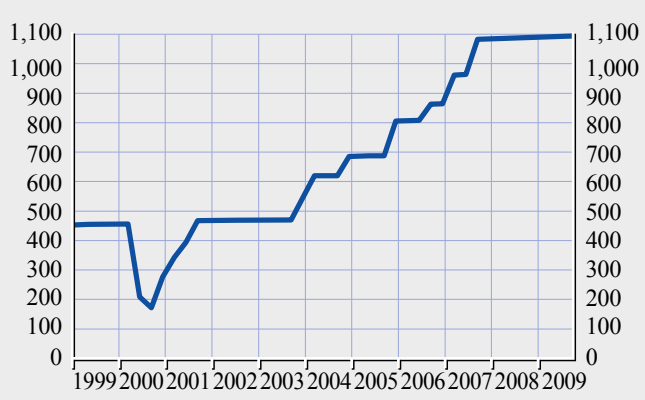

(c) Euro equivalent (bn)

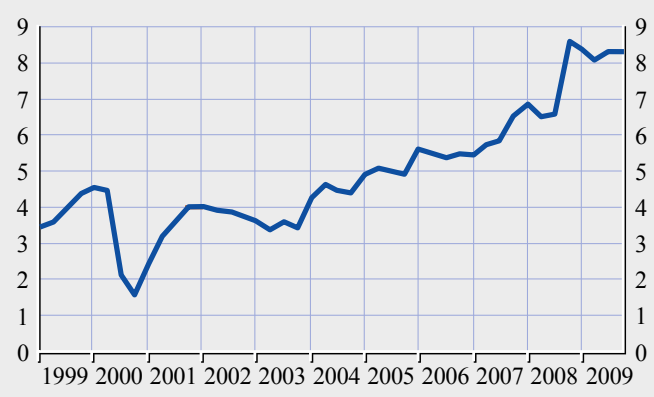

Source: ECB. (b) Exchange rate EUR/JPY

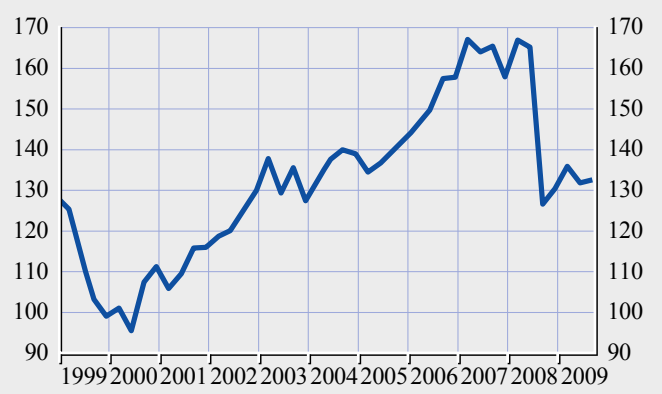

(d) Exchange rate and volume components (EUR bn)
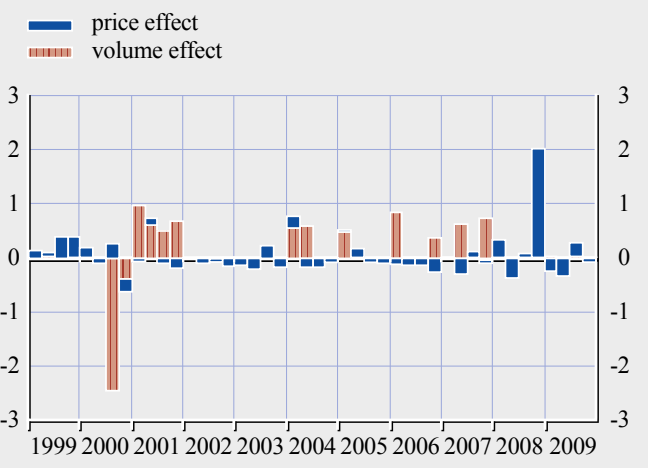

The reason was the continuous depreciation of the euro since the beginning of 1999 , which caused concern about potential misalignments as the exchange rate appeared out of line with euro area fundamentals. In particular, the potential adverse impact on the world economy and price stability in the euro area raised concern. Therefore, the ECB took the initiative for concerted central bank intervention in exchange markets together with the monetary authorities of the United States and Japan in September 2000 and on its own initiative in November 2000. These interventions explain the drop in dollar and yen reserve volumes at end-2000 (see Charts 2(a) and 3(a)). Soon after, the yen reserves were restored by buying yen against dollars.

\section{Gold sales}

Since 1999, the ECB has been signatory of the Central Bank Gold Agreement (CBGA), which aims to limit the effect of gold sales on the gold price, by putting a ceiling on the sales of gold. According to the CBGA the signatory central banks agreed to sell up to 400 tonnes annually during 1999-2004 and up to 500 tonnes annually during 2004-2009. The ECB, like some NCBs, engaged in gold sales within those limits during the latter period, as Chart 4(a) shows. Slightly attenuated by contributions by new euro area countries, the decline of the gold volume amounted $33 \%$ or 246 tonnes less compared to the ECB's initial holding in January 1999 by end-2009.

A general argument for selling gold is that it is not interest-bearing, incurs a storage cost and cannot be liquidated quickly in case of liquidity needs. These disadvantages have to be weighed against the fact that it offers a way of diversifying away from currency 
(a) Volume (tonnes)

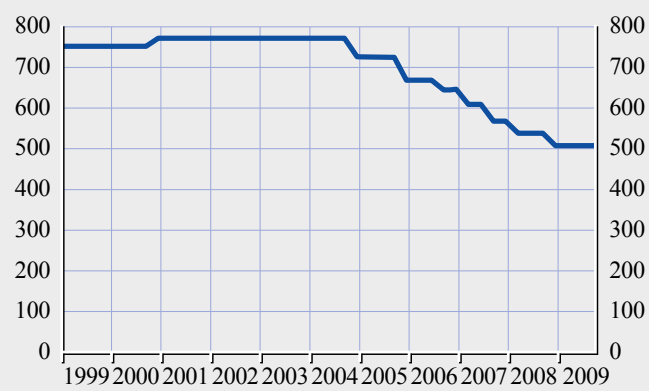

(c) Euro equivalent (bn)

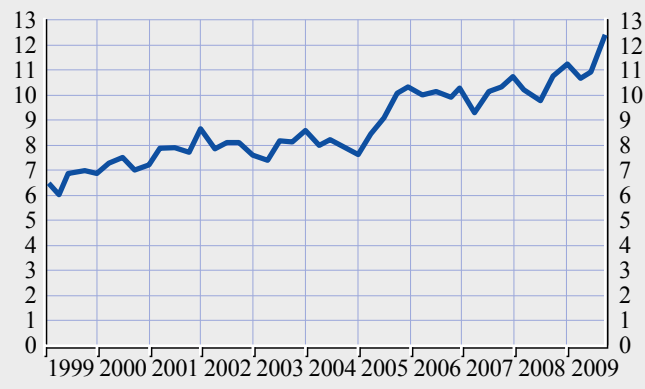

Source: ECB. (b) Price XAU/EUR

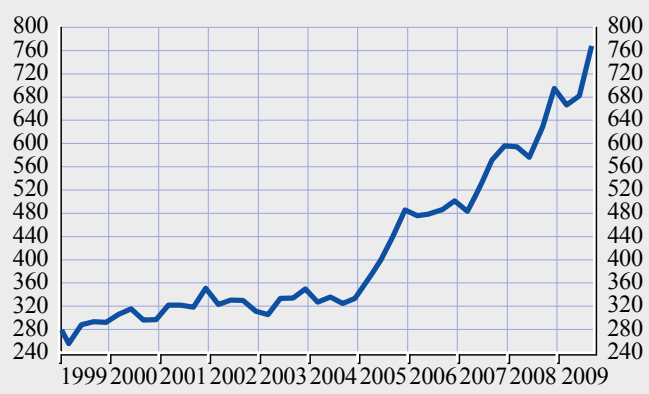

(d) Exchange rate and volume components (EUR bn)

price effect

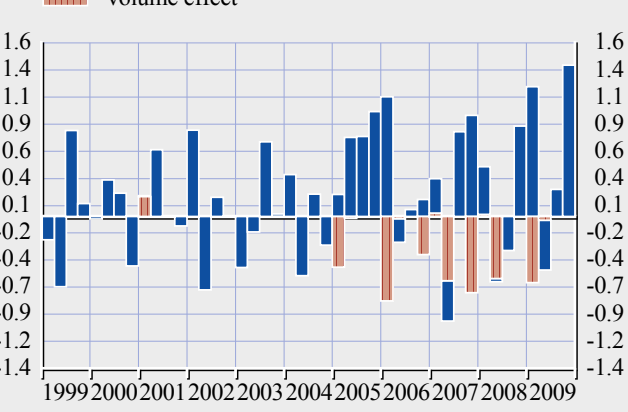

holdings. For example, the rising gold price helped to counter the impact of the depreciating US dollar over the period from 2005 to 2008 . Gold also offers a hedge against inflation in contrast to money. Furthermore, it is seen as a safe investment in times of distress and gold is expected to remain generally accepted and traded in quite a liquid market.

The proceeds from the ECB's gold sales were invested mainly in Japanese yen, which helps to explain the sharp increase in the Japanese yen reserves shown in Chart 3(a).

\section{Rebalancing}

In 1999, the dollar reserves and yen reserves represented respectively $90 \%$ and $10 \%$ in euro equivalent terms of the initial US dollar and Japanese yen portfolio. This remained so until 2003, except during the market intervention in 2000 when first Japanese yen were sold and later rebalanced against US dollar. In 2003, a rebalancing of the foreign currency reserves was decided by the Governing Council, which was implemented from the first half of 2004. Gradually the shares were brought to respectively $80 \%$ and $20 \%$ by the beginning of 2008 , and stood at $78 \%$ and $22 \%$ at the end of 2009 as a result of the weakening of the dollar against the Japanese yen.

This rebalancing is defined based on the relative value of the holdings in euro (see Charts 2(c)-4(c)). The implementation of the rebalancing affects the volume of the holdings in Charts 2(a)-4(a). The rebalancing was a driving factor behind the increase in Japanese yen volume in Chart 3(a), partly realised by contributions from gold sales. 


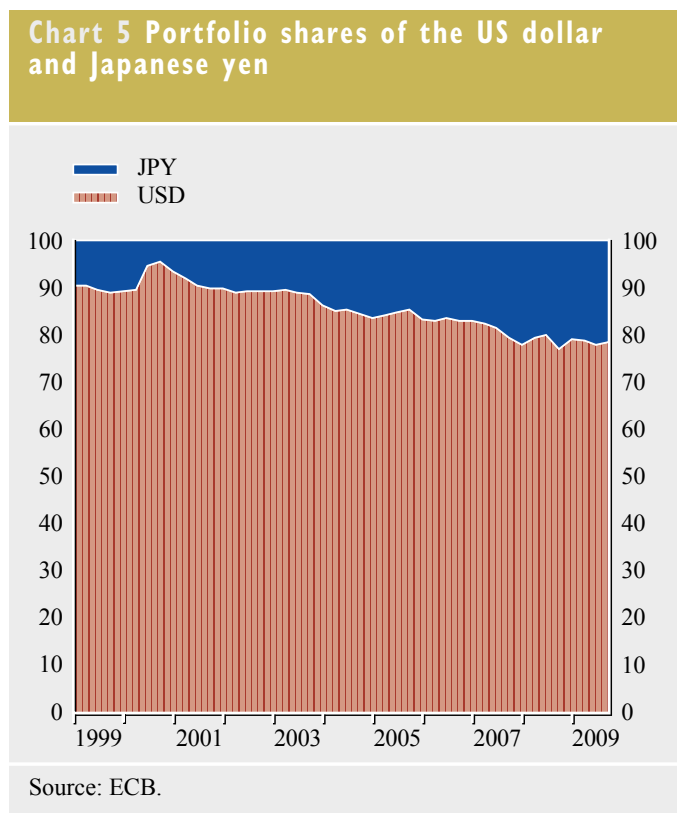

Investment gains and losses and interest income Apart from the gold sales and rebalancing of currency positions, the active management of foreign reserves implies ongoing investment gains and losses that change the volume and composition of foreign reserves. The foreign reserve management is subject to the constraint of keeping liquid resources for any foreign exchange intervention at any point in time. As a result, liquidity and security are the main requirements for the investment of the reserves. Subject to these constraints, the reserves are managed so as to maximise their value.

The investment gains and losses imply small changes in the volume of reserves related to asset price revaluations which add to the effect of interest income earned on the securities they are invested in. The gradual increase in the dollar reserves between 2004 and 2009 as shown in Chart 2(a) corresponds to a typical pattern for consistent earnings on dollar-denominated assets. On one occasion in 2000 , the interest income accrued was sold to maintain the currency split, but this policy was not continued afterwards, mainly due to the interventions later in 2000 which resulted in major US dollar outflows.

\section{EXCHANGE RATE AND GOLD PRICE \\ DEVELOPMENTS}

Exchange rate developments had a significant impact on the value of the foreign reserves in euro. Chart 2(b) shows how the euro first depreciated against the dollar until 2001. After the foreign exchange intervention in late 2000, the euro started to appreciate. Between 2002 and 2004, the euro appreciated strongly to reach EUR/USD 1.36 at end-2004 mainly related to a deterioration of the growth outlook for the United States, the widening US current account deficit and geopolitical tensions. In 2005, the euro depreciated, but then rebounded sharply to reach EUR/USD 1.58 at the beginning of 2008. The continued appreciation of the euro was driven largely by a changing market assessment of the relative cyclical outlook for the two economic areas in favour of the euro area and developments in interest rate differentials. In addition, the persistently large US current account deficit is likely to have contributed to the weakness of the US currency. The euro depreciated significantly vis-à-vis the dollar during the financial crisis of 2008 down to EUR/ USD 1.32 in the first quarter of 2009 , but rose afterwards to EUR/USD 1.43 by end-2009.

The strong movements in the EUR/JPY exchange rate offset each other largely over the 11-year period (see Chart 3(b)). First, the yen appreciated against the euro against a background of significant current account surpluses of Japan and general weakness of the euro to stand at EUR/JPY 95 at the end of the third quarter of 2000. From 2001, the euro started to appreciate gradually related to the deteriorating economic situation in Japan. The appreciation of the euro halted in 2003-04 at about EUR/JPY 135, but continued thereafter. During 2006-07, "carry trade" transactions were seen as one of the factors that contributed to the strengthening of the euro against the yen at times to almost EUR/JPY 170. During the 2008 financial crisis, the euro depreciated sharply to EUR/JPY 126 at end-2008 and recovered only slightly in 2009. 
Chart 4(b) shows how the gold price rose somewhat between 1999 and 2004 from $€ 279$ per ounce to $€ 322$ per ounce at end-2004. In 2005 , it increased sharply to reach $€ 482$ per ounce at the start of 2006. It then remained stable around that price until it again increased sharply from 2007 on to reach $€ 765$ per ounce at the end of 2009. The gold price benefited from the increase in inflation (expectations) and commodity prices, as well as from the weakening of the US dollar. It also served as a safe haven during the financial turmoil that started in mid-2007.

\section{EXCHANGE RATE AND VOLUME EFFECTS}

The euro equivalents of the foreign reserve holdings in Charts 2(c)-4(c) are determined by both the volume changes in Charts 2(a)-4(a) and the price developments in Charts 2(b)-4(b).

The euro equivalent of the US dollar reserves stood at $€ 30$ billion at end-2009, which is about the level the ECB started with in 1999. The intervention in 2000 causing a negative volume effect, the gradual increase in the volume of dollars after the intervention due to earned interest income and the depreciation of the dollar observed over the same period offset each other. This is confirmed by Charts 2(d)-4(d), where the changes in the euro equivalents are split into price and volume effects. At the start of the period, positive price effects occurred when the dollar appreciated, but these were followed by a long series of negative price effects. Moreover, the latter offset the smaller volume increases resulting from investment returns and the occasionally positive price effects. The appreciation of the dollar at end-2008 only partly offset the decrease in the euro equivalent.

The euro equivalent of the Japanese yen holdings more than doubled from $€ 3.4$ billion to $€ 8.6$ billion over the 11-year period. Although the yen depreciated over most of the period, this was reversed at the end of 2008. Moreover, the effect of the depreciating yen was offset by increases in the volume of yen. Chart 3(d) shows how a number of positive volume effects dominate the negative price effects since 2004. These volume increases are related to investments of the gold sale proceeds and the rebalancing of the currency holdings. The strong price effect at end-2008 represents the sharp appreciation, which caused a jump in the euro equivalent. The sharp drop in volume related to the market interventions in 2000 and the subsequent recovery of the volume via rebalancing against the dollar reserves can also be observed in the decomposition.

The euro equivalent of the gold holdings increased by $78 \%$ from $€ 6.9$ billion at the beginning of 1999 to $€ 12.3$ billion at end-2009. Until 2004, the gold price increased gradually along a volatile path, which implied a series of price effects with opposite signs. From 2005 on, strong persistent price increases occurred, which dominated the negative volume effects resulting from gold sales. This implied an increase in the euro equivalent of the gold holdings despite the gold sales.

Overall, the shares of the different assets in the foreign reserve portfolio changed in favour of gold and yen. At the end of 2008, the euro equivalent of US dollar holdings represented $59 \%$ of the reserves (down from $75 \%$ ), while Japanese yen holdings represented $16 \%$ (up from $8 \%$ ) and gold represented $24 \%$ (up from 17\%).

Chart 1 shows that the increase in the euro value of gold holdings offset the decrease in dollar reserves, especially since 2005 . The sharply increasing gold price, which led to a rise in the euro equivalent of the gold holdings, thereby countered the depreciation of the dollar to a certain extent. In fact, the total foreign reserve holdings increased in 2005 and remained around that level until 2008. This also made up for the decrease in reserves during 2003-04. The rising value of the yen reserves expressed in euro, which is mainly explained by gold sales, also countered the depreciating dollar. By end-2008, the appreciating yen and dollar pushed the euro equivalent significantly further above its initial 1999 value of $€ 40$ billion to $€ 50$ billion. 


\section{REVALUATION ACCOUNTS}

On the ECB balance sheet, any realised gains or losses, for example from selling an asset, are booked against the profit and loss account. Any unrealised gains resulting from an increase in the market value of financial assets are recorded as a separate revaluation item. Any unrealised losses that exceed any previous revaluation gains are booked against the profit and loss account. This set-up is a result of the "prudence" accounting principle adopted by the ESCB that requires that the income recognition is carried out prudently as described above.

In order to calculate the revaluation or unrealised gain, the market value of the holdings is compared with their "average cost". The average cost keeps track of the average acquisition price of the asset. In general, when an asset is bought, the average cost of the asset holdings adjusts to the transaction price in proportion to the weight of the acquisition in the total holdings of the asset. When the asset is sold, the average cost does not change. The average cost is updated to the market price used for revaluation purposes only if the market price results in an unrealised loss at the end of a year.

On the ECB balance sheet, revaluation gains are booked separately as an item on the liabilities side. The revaluation amount is a total of the unrealised gains per asset, i.e. unrealised gains are not netted against unrealised losses of other assets.

A number of observations can be made which also follow from the revaluation account rules and exchange rate developments. The revaluations due to exchange rate movements have been most significant, i.e. more so than asset price revaluations. The prudent approach has proved appropriate for the US dollar holdings during the 11-year period, because the unrealised gains during 1999-2002 and 2005-2006, when the dollar appreciated, turned out to be temporary. Treating these unrealised gains as profit would have resulted in more significant losses being taken to the profit and loss account in periods in which foreign reserve currencies depreciated. In relation to gold, a significant revaluation gain has accumulated, especially since 2005 . These unrealised gains mainly reflect the strong market price increase and the fact that no unrealised losses occurred at the year-end. The revaluation of the Japanese yen holdings was relatively unimportant. This is partly due to the frequent inflows into Japanese yen reserves, implying that the average cost adjusted as often and tracked the market price relatively closely. Moreover, a number of year-end unrealised losses for the Japanese yen holdings also contributed to this via the corresponding updates of the average cost. At the end of 2008, however, the revaluation account increased significantly when the Japanese yen appreciated sharply.

\section{I.2 OWN FUNDS PORTFOLIO}

The ECB's own funds portfolio reflects the investment of its paid-up capital, the counterpart of the provision against foreign exchange, interest rate and gold price risks, the general reserve fund and income accumulated on the portfolio in the past. The objective of its management is to outperform its strategic benchmark over the medium term. The own funds strategic benchmark reflects the return-risk preferences of the ECB and aims to maximise the expected return of the portfolio subject to the objective of outperforming a historical average of the ECB's main policy rate (usually the interest rate applied to the ECB's main refinancing operations) at a certain confidence level and over a certain horizon. The portfolio is invested in euro-denominated assets and booked under the heading "other financial assets" on the ECB balance sheet. The own funds portfolio provides the ECB with (interest) income, which helps to cover its operating expenses.

Investment gains and capital have contributed to the size of the own funds, but the portfolio has especially grown due to inflows from the investment of the provision. At the year-end, surpluses have often been kept as provisions and reserves, which were subsequently 
invested in the own funds portfolio. The own funds amounted to $€ 3.5$ billion in 1999 . In 2000, the intervention to support the euro exchange rate implied significant gains from selling US dollars and Japanese yen, which were used to establish a risk provision. The provision was partially invested in the own funds portfolio in 2001. ECB profits in 2001 and 2002 were partly taken to the general reserve fund of the $\mathrm{ECB}$ and subsequently invested as part of the own funds portfolio (the next year). Losses due to the depreciation of the US dollar and Japanese yen absorbed the entire risk provision and general reserve in 2003 and 2004. In 2005, it was decided to set up a new risk provision. During 2005-08, profits were taken to the new risk provision and transferred to the own funds portfolio for investment the next year. At end-2009, the own funds portfolio stood at $€ 11.8$ billion.

\subsection{LIQUIDITY-PROVIDING OPERATIONS IN FOREIGN CURRENCY DURING THE FINANCIAL CRISIS}

From mid-2007 onwards, the Eurosystem and other central banks were faced with much higher liquidity needs from the banking sector due to the disruption of the euro and other money markets. The Eurosystem supplied the necessary liquidity in order to steer the short-term interest rate to its target. At the same time, the Eurosystem took its responsibility as a lender of last resort, and its task to maintain financial stability also motivated bigger and additional operations.

The monetary policy implementation of the Eurosystem is coordinated by the ECB, but carried out by the NCBs. The ECB did, however, take part in additional operations that aimed to provide foreign currency to Eurosystem counterparties. These operations started at end-2007 and became a third factor that significantly affected the size of the ECB balance sheet. First, the liquidity-providing operations involving the ECB are described and then their effect on the balance sheet is presented.

\subsection{LIQUIDITY OPERATIONS IN FOREIGN CURRENCY AND PROVISION OF EURO TO OTHER CENTRAL BANKS}

On 12 December 2007, the ECB together with a number of other central banks announced new measures designed to address the elevated pressures in short-term (US dollar) funding markets. The Governing Council of the ECB decided to take joint action with the Federal Reserve by offering US dollar funding to Eurosystem counterparties.

Between December 2007 and January 2010, the Eurosystem conducted US dollar liquidityproviding operations, in connection with the US dollar Term Auction Facility (TAF), against ECB-eligible collateral, i.e. euro-denominated assets. US dollars were provided by the Federal Reserve to the ECB by means of a temporary reciprocal currency arrangement (swap line). The dollars were then passed on to the NCBs which provided them to Eurosystem counterparties in accordance with the results of the ECB tender operation. The interest rates applied to the transactions between the Federal Reserve and the ECB and between the ECB and the NCBs were those which the Federal Reserve set for its corresponding transactions with its US counterparties. The size of the reciprocal currency arrangements with the Federal Reserve was adjusted on several occasions to accommodate increases in the needs. The initial operations were not rolled over and were left to expire in February 2008. In March 2008, after tensions increased in the run-up to the rescue of US investment bank Bear Stearns, the operations were relaunched. By the end of 2008, tensions in the financial markets had grown further due to the uncertainty created by the collapse of Lehman Brothers. The initial maximum amount of USD 20 billion (spread over two overlapping operations) was gradually increased to USD 70 billion under the TAF agreement by the end of the third quarter of 2008. The initial maturity of 28 days was also extended to 84 days for a large part of the amount. Additional measures were taken in the form of overnight operations for amounts 
up to USD 30 billion and one-week operations of USD 35 billion. From 16 October 2008 on, fixed interest rate tenders with full allotment were carried out with 7,28 or 84-day maturity. From then on, the overnight operations would only take place if deemed necessary.

From 23 October 2008 on, the Eurosystem also carried out foreign exchange swap tenders (apart from reverse operations) with its counterparties against euro cash, at a fixed price expressed in swap points, with full allotment. The EUR/USD foreign exchange swaps were discontinued at the end of January 2009 due to limited demand.

Euro area banks also had problems accessing Swiss franc funding. From 20 October 2008 on, the ECB and the Swiss National Bank (SNB) conducted EUR/CHF foreign exchange swaps with their respective counterparties, providing CHF to counterparties against EUR. From 5 November 2008, 84-day swap operations were carried out. After 16 January 2009, one-week EUR/CHF foreign exchange swaps continued providing Swiss francs against euro to improve liquidity in the short-term Swiss franc money market. Furthermore, the SNB held an account with the ECB for the placement of EUR funds received by the SNB from similar types of operations with other central banks and from its counterparties.

Furthermore, banks outside the euro area had problems accessing euro liquidity. On 16 October 2008, it was announced that the Magyar Nemzeti Bank (MNB) and the ECB would set up repurchase transactions, which provided the MNB with a facility to borrow up to $€ 5$ billion. On 27 October 2008, a currency arrangement between Danmarks Nationalbank and the ECB was announced. The operations would consist of EUR/DKK swap operations up to an aggregate outstanding value of a maximum of $€ 12$ billion at any given time. Danmarks Nationalbank offered the euro funding to its counterparties. On 6 November 2008, an agreement between Narodowy Bank Polski (NBP) and the ECB to provide euro liquidity was concluded and provided the NBP with a facility to borrow up to $€ 10$ billion. On 10 June 2009, it was announced that the ECB had activated the swap line with Sveriges Riksbank which had already been agreed in late 2007. The Riksbank could borrow up to $€ 10$ billion for a maturity up to three months.

\subsubsection{IMPACT ON THE BALANCE SHEET}

Chart 6 presents the size of the liquidity operations that the ECB undertook with non-euro area central banks. It shows how the total of the operations with the Federal Reserve accelerated and totalled on average $€ 217$ billion between mid-October 2008 and mid-January 2009. The operations with other central banks were smaller and totalled on average $€ 34$ billion between mid-November 2008 and mid-January 2009.

The total amount of the operations grew strongly at the end of 2008, but gradually faded out during 2009. The US dollar repo operations moderated over time, while the much smaller US dollar swap operations ended in April 2009. The size of the positions with the SNB remained almost constant and the size of the positions with the other central banks remained small.

In January 2010, the ECB in agreement with the Swiss National Bank decided to discontinue the Swiss franc liquidity-providing operations. In coordination with other central banks, the temporary swap lines with the Federal Reserve were also discontinued following the improvements observed in the functioning of financial markets.

No operations with the NBP took place and hence this facility was not used.

Chart 7 shows the size of the ECB asset (+) and liability (-) items on a quarterly basis and clearly shows the expansion of the balance sheet due to the special operations. The balance sheet more than tripled in size between the second quarter of 2007 and the fourth quarter of 2008, before it decreased gradually in 2009 as the special operations matured. The intra-Eurosystem claims and liabilities denominated in euro also increased. 


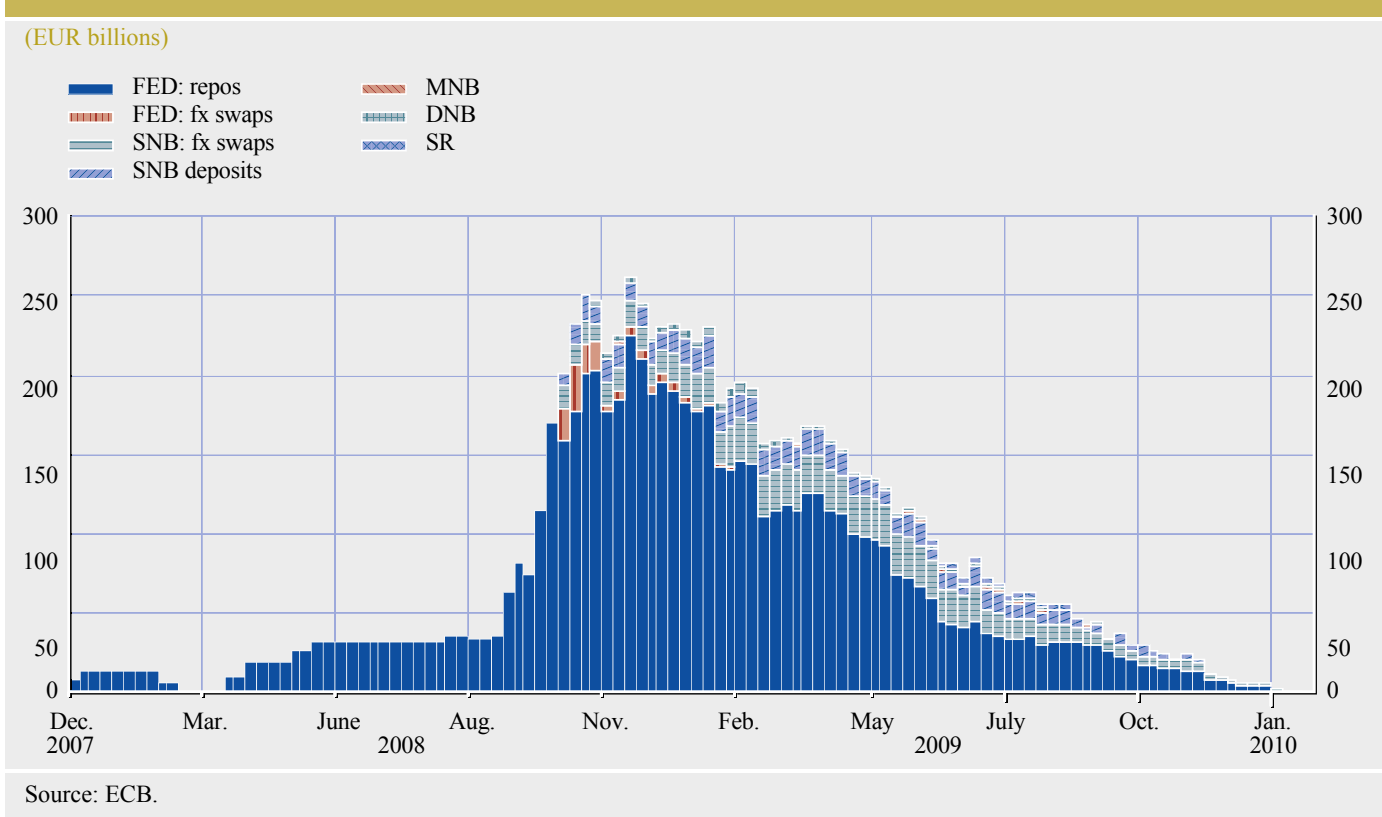

Although the ECB only acted as an intermediary between the non-euro area central banks and the NCBs, the transactions, in line with the ESCB accounting rules, did not net out, and resulted in an increase of the size of its balance sheet. The increase was caused by the euro leg of e.g. the USD-EUR swaps. In particular, the settlement of the EUR leg of the transactions

\section{Chart 7 ECB balance sheet assets $(+)$ and liabilities (-)}

\section{(EUR billions)}
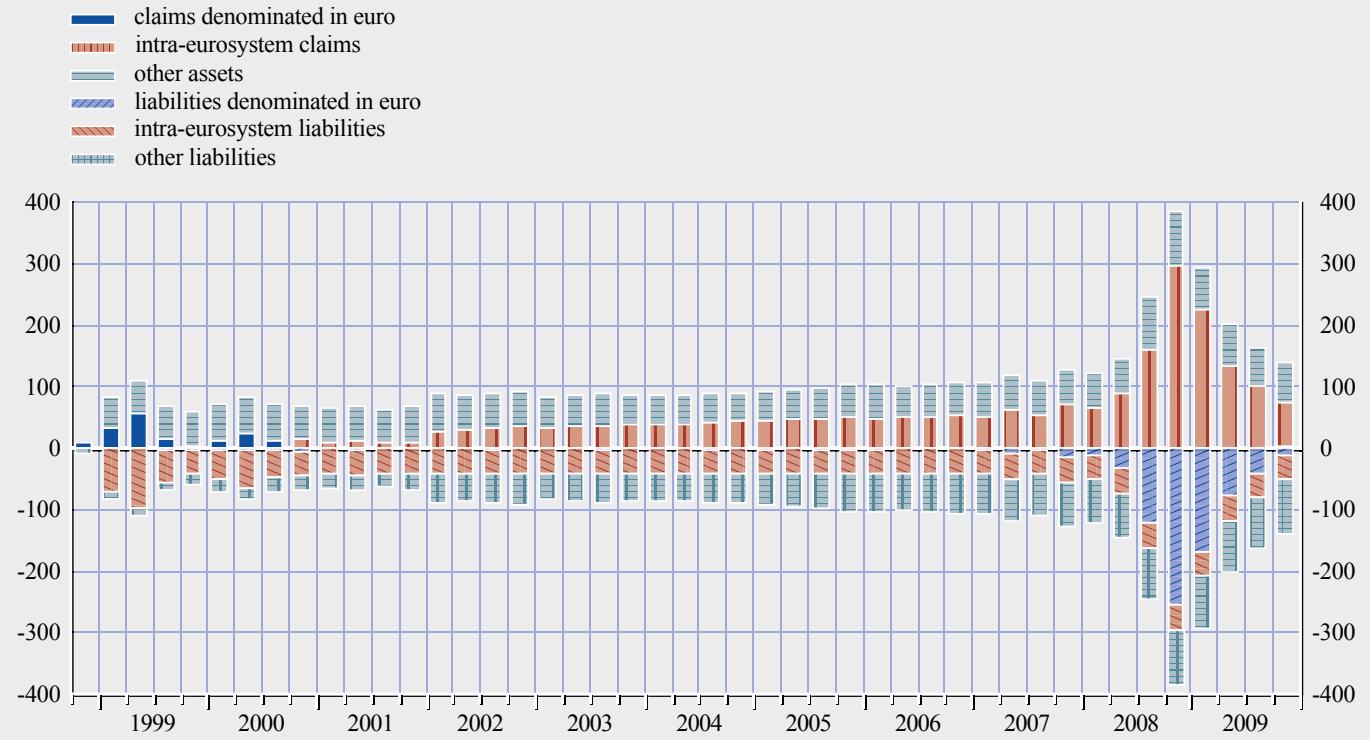

Source: ECB. 
conducted with the NCBs led to an increase of ECB "intra-Eurosystem claims" of on average $€ 217$ billion in late 2008 . In addition, the corresponding swap transactions with the Federal Reserve resulted in a large increase in "liabilities to non-euro area residents denominated in euro" (it should be noted that the euro part of the swaps with the Federal Reserve did not settle but rather created a liability).

The other smaller operations increased a number of balance sheet items somewhat. The settlement of the Danish krone or Swedish krona leg of the swap transactions with respectively Danmarks Nationalbank or Sveriges Riksbank increased the "claims on non-euro area residents denominated in foreign currency". The swap transaction between the ECB and NCBs to provide Swiss francs resulted in "intra-Eurosystem balances". The liability of the ECB to the Swiss National Bank increased the "liabilities to non-euro area residents denominated in euro". In addition, the latter item contains the euro deposits placed by the Swiss National Bank at the ECB. "Claims on non-euro area residents denominated in euro" contained the claim on the Magyar Nemzeti Bank in connection with repurchase transactions. The financial implications of these operations are discussed in Section 3.

\subsection{ECB BANKNOTE ISSUANCE}

The ECB's balance sheet increased gradually due to the strong demand for euro banknotes. According to Article 106 of the EU Treaty, the ECB has the exclusive right to authorise the issuance of euro banknotes. In practice, the euro banknotes are put into circulation by the NCBs and the ECB has been assigned a share of $8 \%$ of the total banknotes in circulation as presented in Chart 8. Until end-2001, only national banknotes were in circulation and these were recorded on the balance sheets of the individual NCBs. Since 2002, euro banknotes are in circulation and the ECB's share appeared on its balance sheet. This share implies a claim by the ECB on the NCBs, as the ECB itself does not put banknotes into circulation.

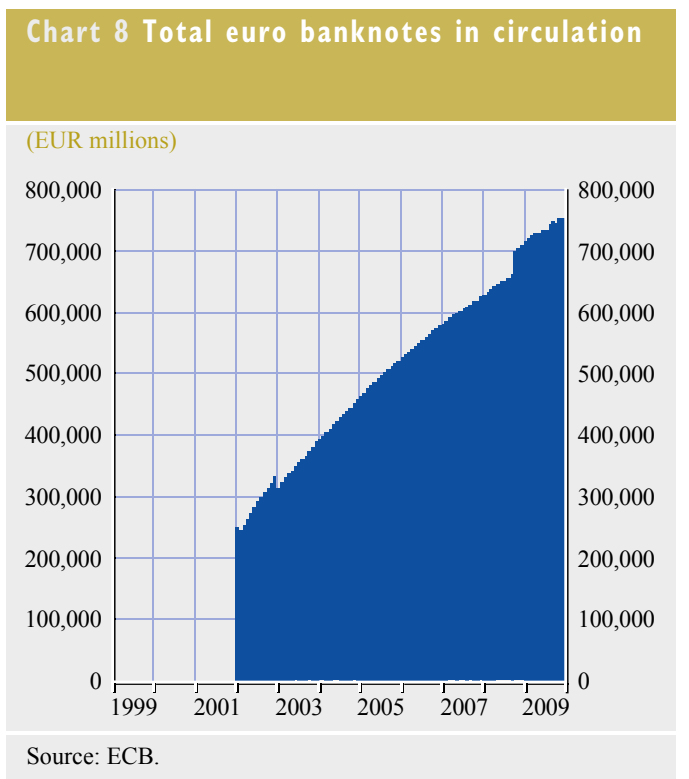

The demand for euro banknotes proved to be consistently strong. As a result, the ECB intraEurosystem claim related to the banknote issuance grew gradually over time from $€ 10,638$ million at the beginning of 2002 to $€ 64,513$ million at the end of 2009. Together with banknotes in circulation (i.e. the mirror item on the liabilities side), it made the total balance sheet grow gradually. The gradual increase can be observed for the period 2002-07 in Chart 7, but was overshadowed by the special operations after 2007. 
income has decreased for many central banks over time, but remains a reliable income source During the first 11 years, the variability of the ECB financial result was naturally related to the main drivers of the balance sheet items discussed in Section 2. The way these drivers affected the ECB profit and loss account is discussed. In particular, this section presents the main income and expense drivers and points out which items they affect on the ECB profit and loss account. Furthermore, the ECB's financial buffers are presented and the way these were used to smooth surpluses and cover losses is explained.

Three main income and expense drivers are identified. First, banknote demand and nominal interest rates, which give rise to income from the issuance of euro banknotes (i.e. seigniorage), were important components of ECB income. Second, financial market developments had an important impact on the financial result, mainly due to the exposure of foreign reserve holdings. Third, the financial crisis at the end of the period is identified as a potentially important driver, although its impact was limited up to 2009.

\section{I MAIN INCOME AND EXPENSE DRIVERS}

The ECB's regular income is derived primarily from investment earnings on its holdings of foreign reserve assets and from interest income on its $8 \%$ share of the euro banknotes in circulation. Furthermore, the exposure of the foreign reserve holdings to exchange rate, asset price and interest rate risks implies that its financial result is significantly determined by revaluations. The importance of these factors can be derived from the profit and loss account overview in the Appendix, where these items are separately reflected. Here, the income and expense drivers are discussed in more detail.

\section{I.I SEIGNIORAGE AS A FUNCTION OF BANKNOTE DEMAND AND THE MONETARY POLICY STANCE}

As inflation moderated in developed economies in the last decade, the average seigniorage

in the long run, and helps central banks to maintain their financial independence.

The monetary income of the Eurosystem mainly consists of interest income arising from the liquidity-providing operations due to the refinancing needs of the banking system. Those refinancing needs primarily stem from the issuance of euro banknotes whose volume is a function of euro banknote demand. The income earned by Eurosystem central banks is linked to the interest rate applied on liquidityproviding operations, which is usually close to the marginal rate of the main refinancing operations (MROs), slightly higher than the main policy rate of the ECB. The amount of liquidity supplied by the Eurosystem is based on an estimate of the demand such that the shortterm money market interest rate remains close to the policy rate, i.e. the minimum bid rate of the main refinancing operations. The monetary income consists of this interest income minus certain expenditures. The main expenditure is the interest paid on the amount of required reserves the monetary financial institutions hold with the Eurosystem. This interest rate paid is the average MRO rate such that on average the required reserves do not provide income to the Eurosystem. Any excess reserves kept with the Eurosystem are not remunerated and therefore profitable to the Eurosystem, but are typically small $(<0.5 \%$, for that same reason, because it is costly to commercial banks). The central banks only incur a small cost for printing banknotes, hence the so-called seigniorage income represents most of the Eurosystem's monetary income.

The ECB receives interest on its $8 \%$ share of the total euro banknote issuance. As the ECB does not put the euro banknotes into circulation, it holds a claim on the NCBs of the Eurosystem which fulfil that task. Interest on the claims of the ECB in respect of its share of banknotes is earned at the latest marginal rate (or fixed rate) for the Eurosystem's main refinancing operations. 


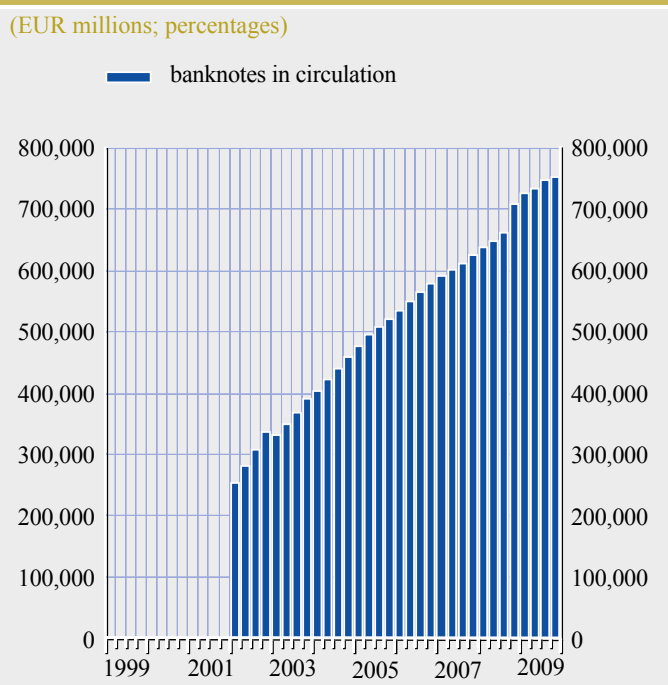

Source: ECB

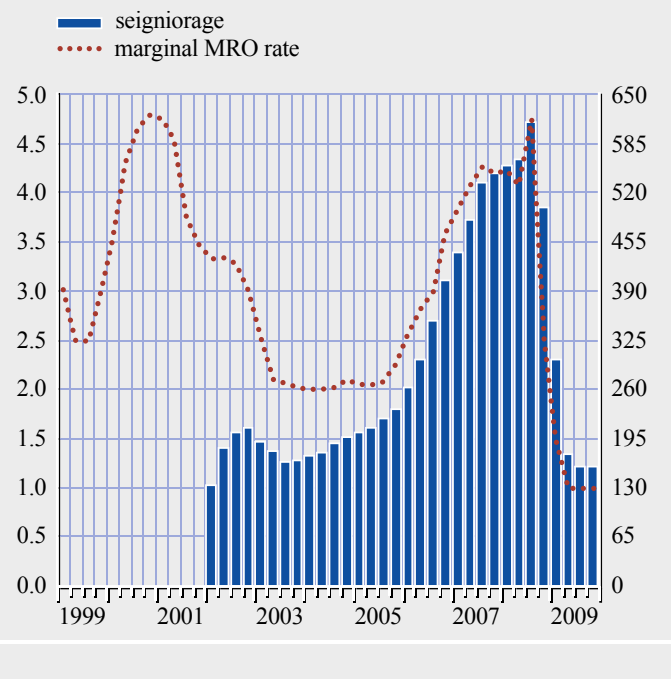

The seigniorage has been boosted by strong banknote demand since the changeover in 2002. Chart 9 shows the increase in total banknotes in circulation, which implied that the ECB banknote share tripled from $€ 20$ billion at end-2002 to over $€ 60$ billion by end-2009. For a given marginal MRO rate, the growth in banknotes raised the potential income from seigniorage.

The often projected decrease in banknote demand due to the use of electronic payments (e-money) has not materialised and is not likely to pose a major threat. For example, Goodhart (2000) provided a number of arguments why currency will not disappear so easily and these arguments have been vindicated. Chart 9 shows the strong trend in the amount of euro banknotes in circulation, but also the ratio of banknotes to GDP (not depicted) increased strongly over time, indicating an increase in currency use.

The marginal MRO rate is also a crucial factor of ECB seigniorage, which introduces more variation in seigniorage. This can be observed by comparing the charts in Chart 9 . The rate varied considerably over the period and made seigniorage strongly correlated with the marginal MRO rate. The decreasing marginal MRO rate at the start of the period implied that the seigniorage stagnated in the period 2002-03, despite the increase in banknotes. Similarly, the rate and seigniorage strongly increased from 2005 onwards and dropped at end-2008.

In this analysis, the marginal MRO rate is taken as given when it comes to ECB income, and hence seigniorage is endogenous. The steering of the policy rate (and MRO rate) only serves the ECB's primary objective of price stability, and profit maximisation does not play any role.

\section{I.2 FINANCIAL MARKET DEVELOPMENTS AND RESERVE MANAGEMENT}

The substantial foreign reserve and own funds portfolios of the ECB result in gains and losses through portfolio management operations and developments in asset prices, exchange rates and interest rates. Central bank foreign reserves are typically not hedged. As a consequence, revaluations through price and exchange rate movements have an important impact on the financial position. Moreover, this implies that the asset side of the balance sheet does not necessarily match the liabilities in terms of return. The reserve management is also subject 
to liquidity and security conditions, which limit the return potential. Below, the impact of financial market developments and reserve management is discussed, while making a distinction between realised gains/losses from trading securities, write-downs resulting from revaluations and interest income developments.

\section{REALISED GAINS AND LOSSES}

The realised gains/losses were dominated by gains from the foreign exchange intervention to support the euro exchange rate in 2000-01 and gold sales during 2005-09. Realised losses remained limited and were dominated by realised gains, but this is partly due to the Eurosystem's accounting rules. Chart 10 presents the realised gains and losses per year.

The biggest realised annual gain from US dollar holdings, amounting to $€ 2,496$ million, resulted from the sales as part of the intervention, while interest rate developments led to a series of smaller gains in the following years. The downward trend in US interest rates during 2001-03 supported security (bond) prices allowing realised gains from sales of US dollar assets, although the depreciation of the dollar in 2002-04 exerted downward pressure on the gains. Similarly, the drop in US interest rates during 2007-09 corresponded to realised gains. The US dollar exchange rate against the euro was volatile over this period, but its overall depreciation suppressed the realised gains to a certain extent. Conversely, the increasing US interest rates during 2005-06 led to small realised losses.

In comparison, the realised gains and losses on the yen and euro portfolios have been modest, but gold sales implied significant gains in the second half of the period. In fact, the realised gains and losses have been tiny for yen investments over the 11-year period, except for the large gain of $€ 867$ million from the yen portfolio's part in the exchange rate intervention in 2000. The realised gains and losses on the euro portfolio followed the pattern in euro area interest rates, with gains in 2001-05 and losses in 2006-07. The gains and losses on the euro portfolio were also small compared with those on the US dollar holdings. A significant contribution to income, however, came from the gold sales that took place during 2005-09 as part of the Central Bank Gold Agreement.

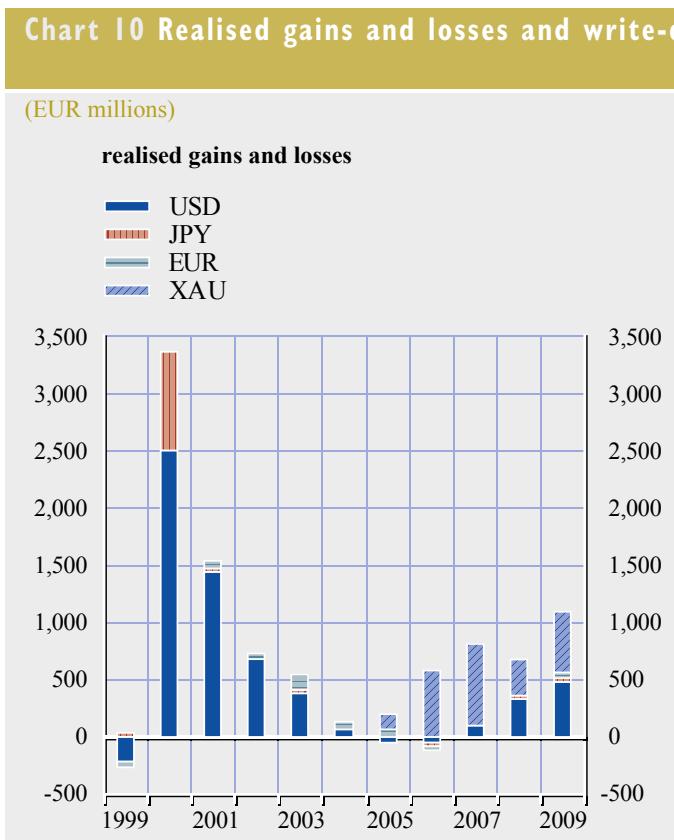

(EUR millions)

write-downs at year-end

USD

กากเ JPY

EUR

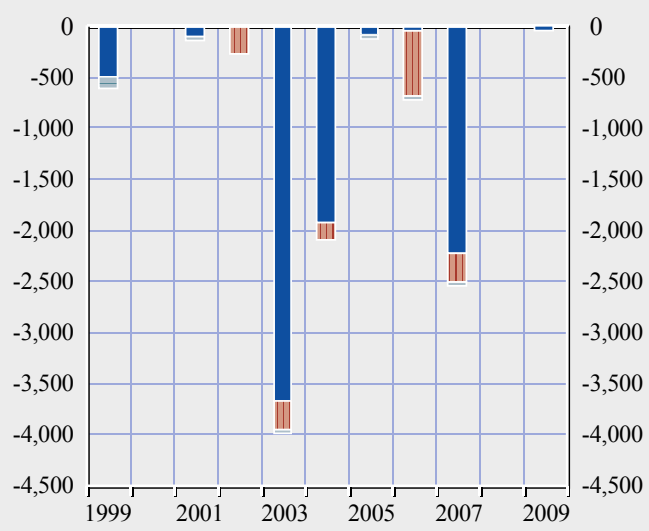

Source: ECB. 
The dominance of gains partly results from Eurosystem accounting rules and realised gains/losses only reveal part of the portfolio performance. Realised gains depend on the revaluation of an asset at the time of its sale (see the discussion on revaluation accounts in Sub-section 2.1.1). These unrealised gains can accumulate in revaluation accounts over time and hence can lead to substantial realised gains. By contrast, unrealised losses are expensed at the year-end and therefore do not accumulate further and will be smaller on average when realised. Unrealised losses hence also need to be taken into account to have an idea about the exposure and performance of the portfolio.

\section{WRITE-DOWNS DUE TO ASSET PRICE \\ AND EXCHANGE RATE DEVELOPMENTS}

Unrealised losses were mainly related to the depreciation of the dollar, and to a smaller extent the yen. According to the Eurosystem accounting rules, an unrealised loss at the year-end results in a write-down on the corresponding asset. Chart 10 presents the unrealised losses at year-end throughout the 11-year period. It can be seen that the largest write-downs were on the US dollar holdings during the periods of dollar depreciation in 2003-04 and 2007. The gradual depreciation of the yen added to that in several years, in particular in 2006. As becomes clear below, especially the write-downs in 2003-04 weighed on the ECB financial result. In comparison to the exchange rate effects, the impact of asset price movements was relatively unimportant.

\section{INTEREST INCOME FROM FOREIGN RESERVES AND THE OWN FUNDS PORTFOLIO}

The overall net interest income from currency holdings was mainly driven by US interest rate developments. The net interest income of a currency holding in euro depends on the size of the position, its interest rate and the exchange rate. The dominance of the US interest income compared with other currencies, shown in Chart 11, is also explained by these components. First, the net interest income on US dollar holdings was relatively large because of the size of these holdings. Second, US interest rates

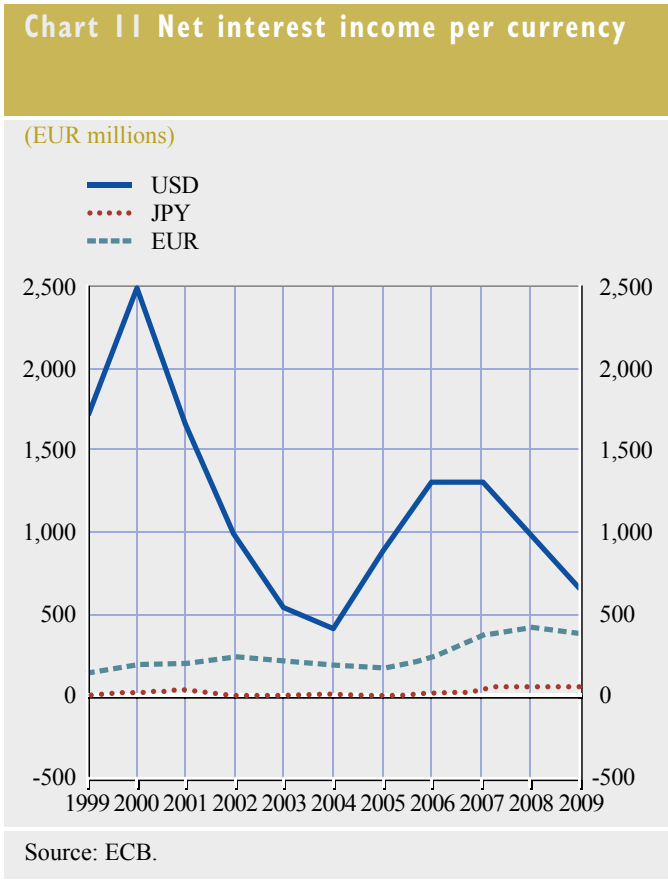

3 MAIN DRIVERS OF ECB PROFIT AND LOSS

were usually higher than those in the euro area and Japan. Third, the depreciation of the dollar decreased the income somewhat, but did not offset the size and interest rate effects.

The net interest income from euro holdings reflects the interest income from the own funds portfolio. Together with realised gains, the return on the own funds portfolio helps to cover the operational expenses of the ECB (administrative expenses, staff costs, etc.), but did not fully cover them every year.

\section{INTEREST PAID ON THE FOREIGN EXCHANGE TRANSFER AND THE INTEREST RATE GAP}

The ECB earns interest on its foreign reserve investments (of US dollars and Japanese yen), but also remunerates the euro-denominated claim due to the initial transfer of foreign reserves by the NCBs to the ECB. In particular, pursuant to Article 30.3 of the Statute of the ESCB and of the ECB, the Governing Council decided that the NCB claims should be denominated in euro using the valuations at the time of the transfer (hence fixed), and should be remunerated on a daily basis at the latest available marginal MRO rate, adjusted to take account of the zero rate 
of return on the gold component. In practice, this means that the amount of the original transfers is fixed in euro terms and remunerated at $85 \%$ of the latest marginal MRO rate, since gold represented $15 \%$ of the total transfer and earns no remuneration (i.e. it is not invested in interest-bearing instruments). In other words, the development of the MRO rate determines the path of the interest expense for the transfer of foreign reserves.

The ECB is exposed to the gap between the interest earned on the foreign reserve assets and the interest paid on the euro-denominated claim due to the initial transfer of foreign reserves. Chart 12 presents the related charts. There is a mismatch between both as the income depends mainly on US interest rates, while the expense depends on the MRO rate. The interest rate gap implies a discrepancy between the interest income and expense. Chart 12 presents the policy rates in the United States and euro area as a proxy for interest rate dynamics in these areas. The correlation of interest income and expense, respectively, with these rates is clear (despite the maturity mismatch). Furthermore, as the euro area rates and US rates were significantly correlated over time, the interest income and interest expense on foreign reserves have been close and the income gap has been small in most years.

\section{I.3 IMPACT OF THE 2007-09 FINANCIAL CRISIS ON ECB FINANCIAL RETURNS}

The crisis which started in 2007 has had a negative financial impact on the ECB, but it also triggered favourable revaluations up to 2009 that act as a buffer outside the profit and loss account. The financial crisis affected the ECB's financial result through three channels: interest rates, financial market volatility and special operations.

First, a lower policy rate implies lower seigniorage. If the crisis affects the real economy and upside risks to price stability subside, then a relaxation of the monetary policy stance implies a lower policy rate and hence lower seigniorage income. Chart 9 shows a drop in seigniorage at the end of 2008, which persisted in 2009. If the policy rate approaches zero, then the marginal MRO rate is close to zero and the seigniorage income evaporates, leaving the ECB with an insufficient source of regular income. As the key MRO rate remained at $1 \%$ in 2009 , the latter has not materialised.

Lower remuneration paid on the foreign reserve transfer may be partly offset by lower income from foreign reserve investments, thus does not play an important role. On the one hand, as the remuneration of the foreign reserve transfer

\section{Chart 12 Interest income and expense related to foreign reserves and interest rate}

\section{developments}
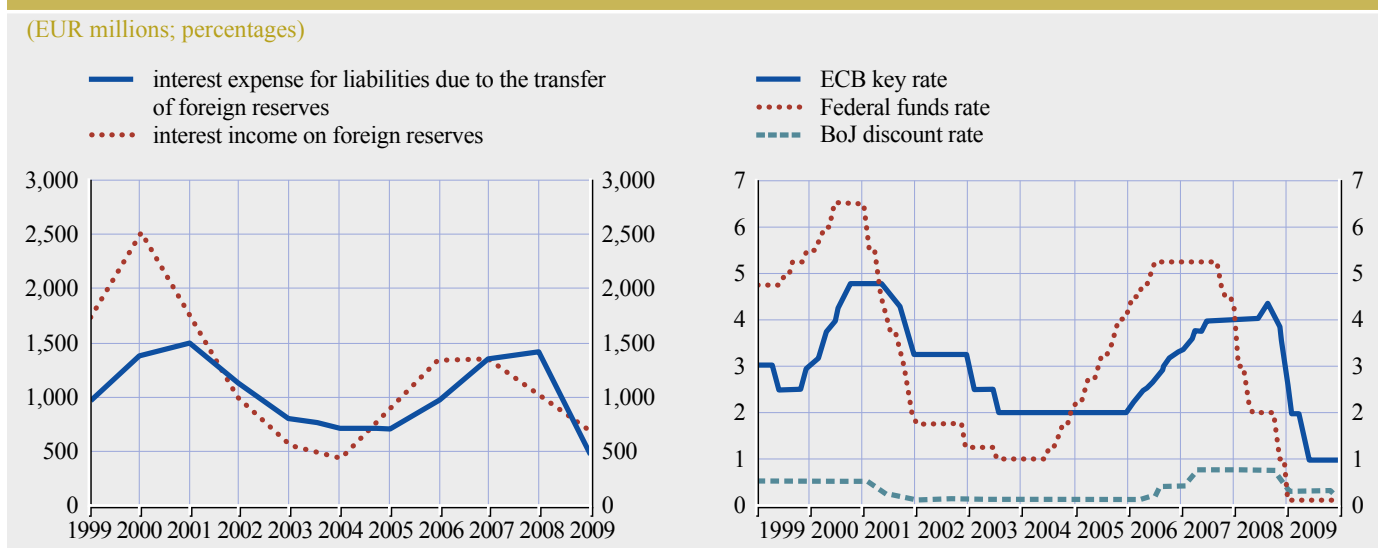

Sources: ECB, Federal Reserve and Bank of Japan. 
depends on the marginal MRO rate, it will be lower. On the other hand, lower foreign nominal interest rates are likely to depress the interest income. A decrease in nominal interest rates on foreign-denominated instruments leads to one-off unrealised mark-to-market gains, at the price of future low or negative returns. In the Japanese case, investment returns have remained depressed for years, whereas in the US case, the phase of low yields was in 2002-03 following the bursting of the "dotcom" bubble and again in 2009.

Second, the exchange rate and asset price developments brought (un)realised gains to the ECB. Although increased financial market volatility implies higher investment risk, the price of government bonds moved up due to safe-haven flows. The Japanese yen exchange rate against the euro appreciated strongly during the crisis, which is attributed to the unwinding of carry trades. The US dollar exchange rate against the euro also appreciated significantly in the second half of 2008, but depreciated again somewhat in 2009. The gold price rose further, likely explained by a flight to safety, while decreasing nominal interest rates supported bond prices. These developments imply realised gains in the event that assets are sold or otherwise unrealised gains that are booked on the balance sheet.

Third, one can expect that special liquidity operations increase the risk, in theory, but they hardly did so for the ECB during this crisis. The extra liquidity operations which were set up during the financial turmoil increase the risk to the Eurosystem NCBs, but much less so to the ECB. As discussed in Sub-section 2.2, the ECB acted as an intermediary between non-euro area central banks and the NCBs in the operations to provide foreign liquidity to Eurosystem counterparties. Admittedly, the operations increased the size of the ECB balance sheet and could in theory imply additional risk through the scale of the operations. However, this can be considered as minimal in the case of the ECB, as its counterparties for those operations were central banks across the ESCB, the SNB and the
Federal Reserve. But the Eurosystem is subject to credit risk in its monetary policy operations and this risk materialised in late 2008 when five counterparties defaulted on refinancing operations. The Governing Council decided that the NCBs should establish their respective shares of a provision as a buffer against risks arising from collateral provided by these defaulting counterparties.

The special liquidity operations involving the ECB had little impact on its income and expenses. The cost in terms of forward points charged for the provision of dollar liquidity via swap operations with the Federal Reserve was paid by the counterparties and passed on via the NCBs to the ECB and so to the Federal Reserve. For the rest, the different legs of this type of operation were not remunerated and left the ECB position unaffected. In particular, the claim that the ECB held on the NCBs during the operation, i.e. the TARGET2 balance related to these operations, was not remunerated. Normally, the ECB is remunerated at the MRO rate on its intra-Eurosystem net claim. However, in the case of the Swiss franc operations, the different legs of an operation were remunerated, but the operations were constructed in such a way as to not materially affect the result of the ECB.

In June 2009, the Governing Council announced a purchase programme for covered bonds whereby the ECB and the NCBs, for monetary policy purposes, started to buy euro-denominated covered bonds issued in the euro area. The share of the ECB in the targeted amount of $€ 60$ billion was fixed at $8 \%$. The purchases are expected to be fully implemented by the end of June 2010 . The programme implies credit risk to the ECB, but the higher yields also provide an additional return. As a result, the initial purchases provided interest income that supported the 2009 result somewhat.

Overall, an assessment of the potential impact on the different profit and loss account items indicates that a negative impact of the crisis on profit can be expected. The decrease in 
seigniorage, which showed a close link with total net interest income in previous years, is especially important. The interest income on foreign reserve assets and the remuneration of NCBs' claims in respect of foreign reserves transferred partly offset each other and are less relevant. The items "other interest income" and "other interest expense" on the profit and loss account are also less relevant, despite their expansion during the crisis (see the P\&L account in the Appendix), because they are mainly related to TARGET2 balances and offset each other. Furthermore, any revaluation gains that the turmoil brings will act as buffers in the future, but as they are not taken as income to the profit and loss account, they will not support that result at this point in time. However, any realised gains from sales and the avoidance of write-downs would to a certain extent support the financial result. These different effects can be observed in the 2009 P\&L account in comparison to previous years.

\subsection{FINANCIAL BUFFERS}

In order to support its financial independence, the ECB has a number of financial buffers in place: a general reserve fund, a risk provision and revaluation accounts. Below, these different buffers are first described after which their implementation is discussed.

\subsection{REVALUATION ACCOUNTS}

The revaluation accounts act as a first buffer against losses on the foreign reserve holdings. A revaluation account captures the increase in value of an asset that is merely due to exchange rate and price developments. The Eurosystem accounting rules prevent such an unrealised gain from being taken as income and possibly distributed to the shareholders, with the reasoning that such a revaluation gain may only be temporary. This prudent approach caps the current income for unrealised gains, but more importantly prevents financial consequences that would occur if the revaluation gains were credited to the profit and loss account but turned out to be temporary. In practice, the revaluation accounts "absorb" at least part of the reduction of the value of the respective asset before any losses are recognised in the profit and loss account. The rules also stipulate, however, that unrealised losses in any one security or currency or in gold are not netted against unrealised gains in other securities or currencies or gold. This implies that unrealised gains and losses can coexist on different assets. Sub-section 2.1.1 discussed the revaluation account developments and how the revaluation accounts have proved their usefulness, in particular for the US dollar portfolio.

\subsubsection{RESERVE AND RISK PROVISION}

The ECB makes use of a general reserve fund and a risk provision, which both enable the bank to cover occasional losses with previous surpluses, but in a different manner. From the start, the general reserve fund was in place. In 2000, a risk provision against exchange rate, interest rate and gold price risks was set up, which after depletion was re-established in 2005.

Firstly, pursuant to Article 33.1 of the Statute of the ESCB and of the ECB, up to $20 \%$ of the profit in any year may be transferred to the general reserve fund, subject to a limit equal to $100 \%$ of the ECB's capital. The remaining net profit is to be distributed to the NCBs, as shareholders of the ECB, in proportion to their shares in the paid-up capital. Losses may be offset against the general reserve, and upon a decision of the Governing Council, against the monetary income of the relevant financial year (see Article 33.2 of the Statute). The transfers to and from the reserve take place after the financial year is closed, i.e. after the annual profit or loss has been determined, and are hence outside the profit and loss account.

Secondly, as mentioned above, a risk provision was established in order to provide an additional buffer against the exchange rate, interest rate and gold price risks of the ECB. The provision can be used to cover realised and unrealised losses at the end of the year, which may not be adequately covered by revaluation accounts. The advantage compared with the general reserve is that it can be built up 
faster. As Chart 13 shows, the risk provision was first set up in 2000, depleted in 2003-04, and re-established from 2005. The size of the risk provision and the general reserve fund together may not exceed the value of the paid-up capital of the Eurosystem NCBs, which stood at $€ 4,020$ million at end-2009. Subject to this upper limit, the size of the provision and continuing requirement is reviewed annually, taking a range of factors into account, including in particular the amount of risk-bearing assets, the extent of materialised risk exposures in the current financial year, projected results for the coming year and a risk assessment involving calculations of Values at Risk (VaR) on risk-bearing assets. In 2010, the Governing Council decided, following the establishment of the covered bond purchase programme, to extend, as a matter of prudence, the scope of the provision to also cover credit risk.

The transfers to and from the provision are part of the profit and loss account and thus affect the annual profit or loss. Surpluses transferred to the provision reduce the profit, while transfers from the provision can cover a negative result. Any remaining profit is to be distributed to the NCBs, as shareholders of the ECB, in proportion to their paid-up capital share. Any remaining loss can be offset against the general reserve (which is then booked the subsequent year) or the Eurosystem monetary income of the same year.

The Governing Council decided to cover the 1999 and 2004 losses with part of the monetary income of the NCBs, as foreseen in Article 33.2 of the Statute. The monetary income is not intended as a buffer for the ECB, but is meant to be distributed among the NCBs. Only if all else fails to protect the ECB paid-up capital can it be used. In 1999, no provisions or revaluation accounts were in place to protect the paid-up capital. A direct charge on the monetary income of the NCBs resulted. In 2004, when both the special provision and the general reserve fund were depleted, the same decision was taken. In 2005, the special provision was replenished in order to prevent charges on the monetary income.

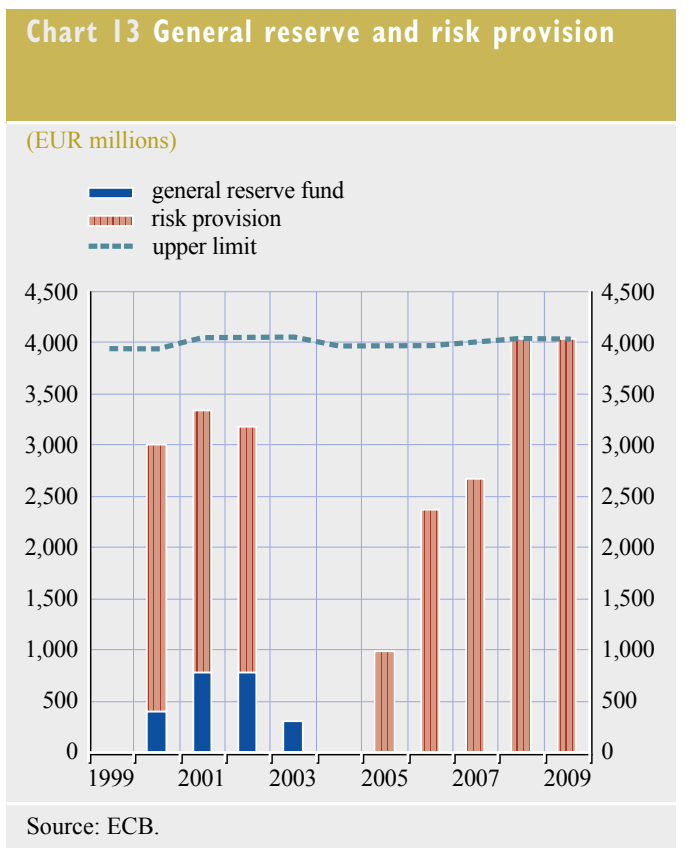

3 MAIN DRIVERS OF ECB PROFIT AND LOSS

\subsubsection{PAID-UP CAPITAL}

At the start of Stage Three of Monetary Union, the ECB was assigned a subscribed capital of $€ 5$ billion. The contribution of each member of the ESCB is determined by the capital key, which is the weight of each ESCB member country in total EU GDP $(50 \%)$ and population $(50 \%)$. The accession of a country to the EU, and its $\mathrm{NCB}$ to the ESCB, increases the subscribed capital of the ECB (see Article 49 of the Statute of the ESCB and of the ECB). As long as an EU Member State does not adopt the euro, it pays only a small percentage of its subscription, and when it joins the euro area it pays up the remaining part. Initially, this was $5 \%$, but this was changed to 7\% in May 2004. Therefore, a smaller amount of $€ 4,000$ million was paid up at the start, with the total increasing slightly to $€ 4,142$ million by 2009 .

If the revaluation accounts, the risk provision and the general reserve fund are not sufficient to cover a loss, then the Governing Council can decide to use Eurosystem monetary income i.e. income of the $\mathrm{NCBs}$ - to cover any remaining ECB losses. In the unlikely event that this also proved to be inadequate, then in principle the 
ECB paid-up capital would have to step in as the final "buffer". If the paid-up capital were to be depleted, a recapitalisation would be required to avoid operating with low or negative capital (see Section 4).

\subsubsection{HISTORY OF SETTING UP AND USING FINANCIAL BUFFERS}

To sum up, a chronological overview is provided of the annual profits and losses, and how the financial buffers were set up/used.

In 1999, the ECB incurred a loss of $€ 247$ million. Falling security prices were a main factor contributing to this loss, because they resulted in substantial end-of-year valuation writedowns. The loss was mainly funded by a direct charge on the monetary income of NCBs, following a decision by the Governing Council to compensate for the fact that the monetary income mechanisms (as laid out in Article 33.2 of the Statute of the ESCB and of the ECB) would not operate until after the changeover to the euro currency in 2002.

In 2000, taking into account the ECB's large exposure to exchange rate and interest rate risks, the Governing Council approved the setting-up of a risk provision against such risks amounting to $€ 2,600$ million. The provision was intended to cover future losses, in particular valuation losses, that may arise from market developments. The provision was financed from the large surplus in 2000 arising from the EUR/USD exchange rate interventions. Investment earnings and sales of foreign currency due to official exchange rate interventions had contributed to this surplus. After establishing the provision, a profit of $€ 1,990$ million remained. $20 \%$ of the profit was transferred to the general reserve (€398 million) and the remaining part $(€ 1,592$ million) was distributed among the NCBs.

In 2001 , a net profit of $€ 1,822$ million was made, of which again $20 \%$ was transferred to the general reserve and the rest distributed among the NCBs. The ECB made a profit of
$€ 1,220$ million in 2002, which for the first time was supported by income on its share of the euro banknote issuance. The profit was entirely distributed to the NCBs.

In 2003, the ECB experienced big writedowns on its financial assets, mainly due to the evolution of exchange rates, which adversely affected the value of the US dollar-denominated assets. Lower domestic and foreign interest rates also contributed to the negative result. After tapping the risk provision for $€ 2,569$ million, a loss of $€ 477$ million remained, which was offset against the general reserve fund.

In 2004, the evolution of exchange rates further adversely affected the value of the holdings of assets denominated in foreign currencies. Furthermore, the low interest income on both domestic and foreign currency assets depressed the total income. The risk provision was already depleted from the year before, implying a net loss of $€ 1,636$ million. The Governing Council decided to offset the ECB's 2004 loss against its entire general reserve fund ( $€ 296$ million) and the remaining loss ( $€ 1,340$ million) against the monetary income allocated to the national central banks.

In 2005, the ECB earned a surplus of $€ 992$ million. The amount was set aside as a special provision against foreign exchange rate, interest rate and gold price risks, leaving a net profit of exactly nil. Similarly, the ECB earned a surplus of $€ 1,379$ million in 2006, which was set aside in the risk provision, while in 2007 , the ECB earned a surplus of $€ 286$ million. The reduction in 2007 was mainly due to the appreciation of the euro against the US dollar and, to a lesser extent, the Japanese yen. The surplus was again set aside in the risk provision. In 2008, a larger surplus of $€ 2,661$ million was made, of which $€ 1,339$ million was transferred to the risk provision, which hereby reached its upper limit, such that $€ 1,322$ million remained as an annual profit and was distributed to the NCBs. As Chart 13 shows, the risk provision thereby 


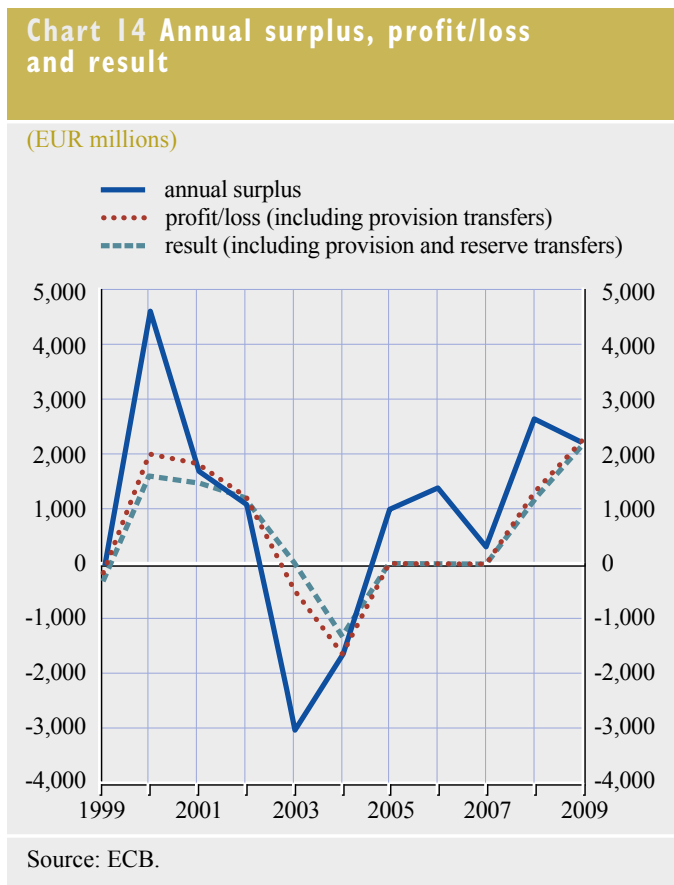

reached the upper limit for the provisions and reserves, equal to the paid-up capital of the Eurosystem NCBs. In 2009, the provision and reserve could not be increased further, and the net profit of $€ 2,253$ million was distributed in full to the NCBs.

It should be noted that the upper limit on the provision and reserves was not reached until 2008. There are two reasons for this. First of all, because an important part of the surpluses had been redistributed during the first years. The latter is partly the result of the $20 \%$ limit on transfers to the general reserve, which automatically implies that the remaining $80 \%$ of the surplus is to be distributed among the NCBs. Secondly, due to the financial market developments that depleted the reserves in 2003-04, such that recovery only started from 2005 onwards. The transfers of the full surplus to the risk provision observed during 2005-07 and a final part at the end of 2008 allowed a faster buffer accumulation than contributions to the general reserves.

The reduction of the reported net loss in 2003 occurred mainly through the risk provision, while the general reserve fund contributed relatively little to covering the loss. Chart 14 shows the annual surplus before any transfers from or to the risk provision and the general reserve fund. It also shows the reported annual profit and loss, which includes transfers to and from the provision. This second line is much flatter than the first one and avoids a big loss in 2003. Finally, it shows the remaining result to be distributed or covered when also the transfers to and from the general reserve fund are taken into account. The reserve made a relatively small contribution and only so in the first half of the period. The provision and reserve were not sufficient to cover the loss in 2004. Section 4 discusses the relevance of such losses and the need to maintain such buffers as part of the analysis of financial strength. 
given moment in time. Third, there have been

The analysis of the profit and loss account in Section 3 made clear that the ECB runs a number of risks that can trigger losses and erode its financial position. This section discusses reasons why the ECB may want to prevent this from happening and assesses the ECB's overall financial strength. According to Stella (2008), financial strength is "the extent to which an entity is constrained by its financial situation in pursuing its strategic goals or policies. An entity is financially strong when it is relatively unconstrained and weak when financial constraints are binding on policy choices." This section presents components of ECB financial strength and risk factors. In doing so, it takes a step back from the financial account charts and discusses the macroeconomic relevance of central bank financial results.

Sub-section 4.1 identifies credibility as a reason for protecting central bank financial strength. Sub-section 4.2 presents important components of ECB financial strength such as its legislative provisions, financial buffers and seigniorage. Sub-section 4.3 discusses risks to financial strength, in particular risks to future seigniorage, from financial market developments and from financial instability.

\section{I WHY DOES THE ECB NEED FINANCIAL STRENGTH?}

The financial position of a central bank is often treated as irrelevant because of the social nature of a central bank's objectives, its money printing monopoly, its ability to operate with negative capital and its state ownership. First, as the primary objective of a central bank such as the ECB is price stability, and profitability is completely subject to that aim, it would appear that its financial accounts are only relevant at the micro level. They matter only to provide transparency on the stewardship of the public enterprise. Second, there is a belief that a financially weak central bank can monetise itself out of financial problems. Therefore, it should not care about eroding capital at any a few examples of central banks with prolonged negative capital positions operating effectively. Situations at the central banks of Chile and the Czech Republic are often taken as examples. Fourth, while it is still considered to be a political issue, a central bank can always be recapitalised by the state.

A number of studies have pointed out, however, that the issue is more complex and that the financial strength of a central bank does matter in relation to policy outcomes at the macro level through its effect on credibility (see e.g. Stella, 2005). As the historical evidence and analysis in these papers show, central bank financial strength can determine the success or failure of monetary policy. The main reason is that the perceptions of a central bank's financial strength have an impact on the credibility of the central bank and its policy. If it is expected that the central bank is not capable of or willing to incur losses, then costly objectives and policies are not credible and the target cannot be achieved or only at a higher cost to the economy.

Financial strength helps the central bank to protect its independence, which is a crucial component of credibility. Furthermore, it allows a credible commitment to the price stability goal and credible interventions during financial instability episodes. Each of these issues is briefly discussed below.

\section{I.I INDEPENDENCE}

A financially strong ECB which does not rely on NCB transfers contributes to the Eurosystem financial strength and helps the Eurosystem to maintain its independence from governments. The role of central bank independence in relation to credibility and policy outcomes has long been studied (see the literature starting, for example, with Barro and Gordon (1983a,b) and Sargent and Wallace (1982) on the relationship with the government). The relationship between the central bank and the government is always subtle when it comes to the credibility of central bank policy. More recently, the results of a regression analysis by Ize and Oulidi (2009) 
on a cross-section of central banks show that the relationship with the government reflects the main difference between strong and weak central banks.

If a central bank depends on transfers from the government, the latter has the opportunity to influence the central bank's policy, e.g. by attaching conditions to the transfers. This poses a threat to the overall independence of the central bank. According to Hawkins (2003), a central bank with negative or even low capital would see its (perceived) independence affected, because it increases the probability that recapitalisation is on its way, potentially accompanied by government attempts to influence decisions. Even if the transfers are minor, they will at least blur the situation and increase uncertainty, especially if at that time the state is in fiscal need or the central bank signals a need to tighten its stance. In short, a central bank needs to safeguard its financial independence to sustain its political and economic independence.

\section{I.2 PRICE STABILITY}

Empirical evidence on a wide range of central banks suggests that financial weakness hampers central banks in the achievement of their inflation objective. Stella (2008) provides such empirical evidence and Klüh and Stella (2008) made a first attempt to estimate the relationship between the financial strength of a central bank and its policy performance. The econometric evidence shows a negative relationship between indicators of central bank financial strength and inflation outcomes.

The link between financial strength, independence and policy outcomes offers one explanation for these findings, but monetisation is a more direct one. If a financially weak central bank does not want to rely or cannot rely on the government, then it needs to resort to printing money or react less aggressively to inflation to support its own income. As Stella (2008) argues: "it can be demonstrated that poorly-capitalised central banks are often constrained in their policy choices or, even when not so constrained, sometimes loosen policy to avoid large losses for reputation or political economy reasons". Such a change in policy, however, conflicts with its price stability objective.

As a result, a central bank cannot monetise itself out of financial problems and achieve price stability at the same time. A situation where monetisation becomes likely would soon harm the bank's credibility, alter inflation expectations and lead to a deterioration in the inflation outcome. The bank can resort to a number of measures to offset the secondary effects of monetisation by repressing the financial system or sterilising its operations by issuing bonds, but those activities are usually considered to be problematic and not sustainable.

The Eurosystem is dedicated to its price stability objective and its credibility such that it wants to rule out printing money as an option. A financially strong position of the Eurosystem excludes any need to resort to printing money. The most direct way to achieve this is for each individual $\mathrm{NCB}$ and the ECB to remain financially strong.

\section{I.3 FINANCIAL STABILITY}

Financial weakness may raise doubts about the feasibility and sustainability of other policies of the central bank. For example, doubts may arise about the central bank's ability to perform its lender of last resort function and deal with the associated risks, or its ability to engage in subsidised lending to a troubled banking sector.

The central bank needs a degree of financial independence through a capital buffer and a sustainable source of revenue, otherwise doubts might arise about the willingness of the central bank to act if the required policy involved costs (which cause a deterioration in its financial position).

This issue especially concerns the NCBs, which are generally involved in Eurosystem emergency liquidity assistance operations within the rules which the ECB has set for this purpose (see e.g. ECB, 2007). 


\subsection{ECB FINANCIAL STRENGTH}

Given the need for financial strength, this sub-section takes a look at the ECB's financial strength and the factors that support it. Naturally, the ECB's capital, the financial buffers to protect this capital, and the profitability analysed in the previous section make a crucial contribution to the financial strength. However, financial strength is not solely composed of the level of capital, buffers and profits; it starts with legislative provisions dealing with independence, capital, reserves, income distribution and loss sharing. The financial strength of a central bank and the adequacy of financial buffers can only be assessed in this context. Furthermore, the policy objective may affect the financial strength of a central bank.

\subsection{LEGISLATIVE PROVISIONS}

The Statute of the ESCB and of the ECB specifies modalities for independence, capital, reserves, income distribution and loss sharing:

- Article 7 of the Statute grants independence to the central banks of the ESCB and their decision-making bodies. Article 14 requires that national legislation reflect this before the country joins and specifies that the Governing Council may vote by a two-thirds majority that other functions performed by $\mathrm{NCBs}$ interfere with the objectives and tasks of the ESCB.

- In accordance with Article 28, the ECB started Stage Three of Monetary Union with a nominal capital of $€ 5$ billion. Furthermore, "the capital may be increased by such amounts as may be decided by the Governing Council acting by qualified majority...". The capital was meant to provide income through investments to cover operational costs of the bank, while at the same time offering a buffer.

- Article 33 deals with the allocation of net profits and losses of the ECB: “... an amount to be determined by the Governing Council, which may not exceed
$20 \%$ of the net profit, shall be transferred to the general reserve fund subject to a limit equal to $100 \%$ of the capital; the remaining net profit shall be distributed to the shareholders of the ECB in proportion to their paid-up shares. In the event of a loss incurred by the ECB, the shortfall may be offset against the general reserve fund of the $E C B$ and, if necessary, following a decision by the Governing Council, against the monetary income of the relevant financial year in proportion and up to the amounts allocated to the national central banks ...".

The legislation implies financial strength by:

- providing independence to the ECB (and NCBs) and protecting them from quasifiscal costs. It also protects the banks from automatic profit distribution or excessive profit transfers to stakeholders/governments, which would weaken the financial position.

- foreseeing capital and the right to build up provisions, which supports the ECB position further.

- improving transparency on income distribution and losses, and the way recapitalisation could take place. This transparency contributes to the bank's credibility.

In addition, the ESCB accounting rules and particularly the principle of prudence prevented the ECB from incurring even greater losses in periods of depreciating reserve currencies through the use of revaluation accounts to record unrealised gains. Setting up general provisions against the risks, to which the ECB is most exposed, is also allowed by the accounting framework in place. In this way, the financial strength of the ECB is significantly enhanced.

As can be concluded from the analysis by Stella and Lonnberg (2008), however, the content of such legislation should be balanced. Attempts to regulate everything a priori may be counterproductive. If it is stipulated, for example, 
that losses will be automatically covered by the shareholders, then this would lack credibility as there is no guarantee that the shareholder would always "stand behind" the bank. In the ECB's case, a decision of the Governing Council is explicitly required to use Eurosystem monetary income to cover losses.

Ize (2007) concluded that weak central banks typically operate in smaller and less wealthy countries, and are burdened by large non-performing assets, compulsory transfers and low capital. This result suggests that there are scale effects, but more importantly it clearly indicates the presence of weak legislative provisions since the banks have been forced into quasi-fiscal operations (non-performing assets), have poor income distribution rules (compulsory transfers) and little support (low capital).

\subsubsection{FINANCIAL BUFFERS}

Apart from the legislative provisions, the way the capital and buffers are handled by the central bank is a second important component of the bank's financial strength. This represents the more visible part of financial strength.

If the institutional environment is favourable and based on solid legislative provisions, then in theory - the level of capital and buffers at a given point in time can afford some flexibility. The reason is that a central bank in this setting will generate enough income in the long run to offset negative results. A temporarily weaker position of the central bank does not necessarily mean that government influence or monetisation are near. Bindseil et al. (2004) present simulation results on these issues and conclude that in practice positive capital seems to remain a key tool to ensure that independent central bankers always concentrate on price stability.

The capital and financial buffers still play an important role, because a weaker financial position can still raise uncertainty about a central bank's willingness to take more losses and confront its shareholder. Concerns about a central bank's willingness to act may have consequences at the macroeconomic level.
Therefore, it is better to maintain a fair (positive) amount of capital and protect it with financial buffers to avoid credibility problems. The rare cases of central banks that run a negative capital position without further implications maintained their credibility thanks to other supporting factors (like expectations of strong future income or a financially strong fiscal counterpart; see e.g. Frait (2005)). At the same time, however, the discussion in the literature on capital adequacy is ongoing and it remains hard to quantify adequate capital. The different financial structures of central banks also render comparison difficult, which implies that the conclusions drawn here for the ECB do not necessarily reflect on other central banks, e.g. the Federal Reserve, which has typically had a lower capital base than the ECB but cannot be seen as financially weak(er). The situation during the financial crisis would make this judgement even harder, because some central banks provided new or different means of financial support to their banking system on behalf of their governments.

The ECB has clearly stated its intention to protect its initial capital. As discussed in Sub-section 3.2, the ECB made use of both reserves and provisions to protect its capital. During the 11-year period, the setting-up of a special provision has been especially beneficial to the ECB.

\subsubsection{POLICY OBJECTIVE AND SEIGNIORAGE}

The financial strength of the central bank is supported by the right to print money, which is a reliable future income source not included in the balance sheet. Therefore, the accounting capital and financial buffers are often seen as incomplete measures of the financial strength of a central bank. In general, implicit liabilities (e.g. financial stability events) and assets (e.g. the right to issue currency) are not recorded in typical accounting frameworks. These potential income and expenditures could, however, easily dwarf existing balance sheet items.

Although, in theory, the steering of seigniorage income could support the financial position to a great extent, it is usually restricted by the 
presence of a nominal policy objective (price stability) that prohibits printing money solely to support the financial position. Therefore, if it is unlikely that the central bank will abandon its inflation target, then the seigniorage income becomes endogenous and the potential to steer seigniorage cannot be taken as financial strength. This also holds for the ECB. Although this endogenous seigniorage is smaller, it provides a reliable income source in the long run that supports the financial strength. Furthermore, in the euro case, practical experience has shown a consistently growing banknote demand while the policy stance changed a number of times (see Chart 9), and one may therefore wonder whether banknote demand could be steered easily, if at all.

\subsection{RISKS TO THE FINANCIAL POSITION OF THE ECB}

As the analysis in the previous sections indicated, the financial position of the ECB is confronted with a number of external risks that test its financial strength. The most important risk factors of a central bank are discussed below, as e.g. also presented in Cukierman (2010), and are related to the experience of the ECB. In particular, the consequences of a drop in seigniorage, financial market developments and financial stability expenditures are discussed.

\subsection{BANKNOTE DEMAND AND DISINFLATION}

Persistently low seigniorage would be a problem, but is currently of no threat to the ECB. If seigniorage permanently falls due to a drop in the demand for banknotes, then this undermines the financial strength of the central bank. As pointed out by Martinez-Resano (2004), this presents a real threat to financial strength, because it undermines the long-term potential income. At the moment, the demand for euro banknotes is strong and there is no such risk, despite the appearance of electronic payment tools (see Section 3).

However, the successful implementation of monetary policy, by bringing inflation and nominal interest rates down to low levels, implied a moderation of seigniorage. As seigniorage still brings a reliable income in the long run, this is less of a threat. In the short run, however, it does mean that seigniorage can become very low when the nominal interest rate approaches zero during a recession.

\subsubsection{FINANCIAL MARKET DEVELOPMENTS}

Financial market developments can erode the financial position through write-downs on the foreign reserve holdings and own funds. Significant foreign exchange positions of major central banks cannot be hedged, because this would influence the market through the size of the position and the foreign currencies are meant to be available in case of intervention needs. Although negative results purely due to price movements are often temporary and tend to revert, they may push an already troubled financial position across the threshold where a recapitalisation becomes necessary. Furthermore, as Stella and Lonnberg (2008) point out, global capital flows have increased over time more than the increase in the size of central bank balance sheets, thereby increasing their leverage. The risk from financial market developments has therefore increased over time.

As the ECB holds a large amount of (unhedged) foreign exchange reserves, foreign exchange rate risk is the most important risk factor (see e.g. the Value-at-Risk charts in the ECB Annual Report and the discussion in the previous sections). This type of exposure differs enormously across central banks around the world and depends on their policy objectives and tasks in this regard.

Interest rate risk may weigh on ECB income, in particular through the "interest rate gap". The higher euro area interest rates are, the higher the expense related to the euro-denominated ECB liability for the transfer of foreign reserves is. The lower rates are in the United States and Japan, the less foreign exchange investments earn. When euro rates are high and foreign rates are low at the same time, then the interest rate gap depresses ECB income. 
However, the interest rates and the gap are linked to the business cycles of the respective economies and therefore it is less likely that a gap persists over a prolonged period of time. Moreover, the business cycles of trading partner countries are often correlated, thereby reducing the size of the gap.

The higher euro area rates are, the higher seigniorage is (given a certain demand for banknotes) and the higher the expense on the $\mathrm{NCB}$ claim due to the transfer of foreign reserve assets is. Seigniorage and the foreign exchange expense will hence partly offset each other for a given change in euro area interest rates. As the amount of banknotes has grown strongly over time, however, seigniorage has grown more strongly than the foreign exchange expense, which is based on the fixed amount of the initial foreign exchange transfer. As shown in the profit and loss account table in the Appendix, seigniorage reached $€ 2,230$ million in 2008, while the foreign exchange expense amounted to $€ 1,400$ million.

\subsubsection{FINANCIAL INSTABILITY}

Episodes of financial instability increase the risk for the central bank in its role as lender of last resort. Related shocks and policy decisions typically increase the size of a central bank's balance sheet and thereby increase the risk to the bank's position. In the case of the ECB, the 2008 financial crisis inflated the ECB and Eurosystem balance sheets strongly as a result of the larger liquidity operations. However, as the ECB only acted as an intermediary between the NCBs and central banks outside the euro area, these operations posed little extra risk to the ECB.

The NCBs ran most of the risk since they provided the liquidity to their counterparties. In case the counterparty defaults, their risk stems from the collateral received in the refinancing operations during episodes of market stress. In this case, they receive collateral on a much greater scale, of an on average lower quality and at a time when the markets in which the collateral trades become less liquid. Up to mid-2009, five counterparties defaulted on their liquidity operations with the NCBs. Provisions were created to cover potential related losses.

The risk associated with the absorption of excess liquidity in the aftermath of a banking crisis appears contained for the Eurosystem. Historically, such operations proved costly to central banks when they needed to issue debt to absorb liquidity, because the interest they owe on these securities may be higher than the interest earned on the assets. In normal times, the short-term Eurosystem refinancing operations allow a relatively quick decrease in outstanding liquidity as they expire. However, the increase in the maturity of the operations (up to one year), as a response to the intensifying financial crisis, has offset this mechanism. Still, liquidity-absorbing operations could be launched when needed. In case the exit would require the liquidation of collateral, potential losses may materialise. The ECB is not directly involved in the liquidity provision and hence does not incur this risk directly.

As mentioned in Sub-section 3.4.3, the ECB covered bond purchases do give rise to credit risk for the ECB, but at the same time it benefits from higher yields on those instruments and from the fact that it now holds a larger share of its assets in euro-denominated securities.

Following financial crises, non-performing assets and obligations of financial institutions are often assumed by the state. The state also often provides rescue loans and finances restructuring. If such bailouts are (partly) financed by the central bank instead of the government budget, then this increases the risk considerably of ending up with nonperforming loans eroding the financial strength of the central bank. Dalton and Dziobek (2005) discuss central bank losses due to activities that go beyond the conventional central banking functions. Up to mid-2009, the ECB had not engaged in such quasi-fiscal operations. 
During financial crises, markets often move in the same direction, thereby increasing correlations. The higher correlations will also be felt on the central bank balance sheet, with extra liquidity operations, lower interest rates, lower inflation and asset market volatility coinciding and all increasing the risk to the financial position of the central bank. At a global level, financial markets have grown and made contingent liabilities larger, hence increasing the leverage and risk for a lender of last resort.

By contrast, Ize and Oulidi (2009) found balance sheet volatility to be a good predictor of profitability, suggesting that the more active central banks - or central banks operating in more turbulent macroeconomic environments become more exposed to extraordinary gains and losses. This suggests that if the risks do not materialise the central bank can be left with a (unintended) profit despite the financial crisis. In the same sense, financial turmoil can be devastating for the relationship with governments, but it can also be an opportunity to affirm an existing healthy relationship or for new cooperation.

In the case of the Eurosystem, there were write-downs, but also profits during the crisis. In particular, the NCBs earned income on the surplus of liquidity that banks kept with the Eurosystem during the financial crisis. Eurosystem counterparties obtained euro liquidity at the MRO rate, but the surplus that was placed back with the Eurosystem overnight is only remunerated at the lower deposit rate. This behaviour of counterparties likely reflected an unusually strong preference for liquidity which induced an expanded intermediary function of the Eurosystem, meaning a higher profit but also higher risks. 
5

\section{CONCLUSIONS}

This paper has analysed trends in 11 years of ECB financial accounts. Three main drivers of the balance sheet items and profit and loss account items have been identified and analysed: financial market developments and reserve management; financial turmoil and related liquidity operations (in foreign currency); and banknote issuance. Furthermore, an assessment of the financial strength of the ECB has been made based on these accounts and findings in the literature.

1. The analysis of the drivers of the balance sheet items came to the following findings. First, financial market developments were identified as an important factor leading to significant revaluations of the foreign reserve assets and reserve management had a significant impact on the size of the positions. A decomposition of the changes in the foreign reserve holdings into exchange rate and volume effects was carried out. Prominent volume effects were the foreign exchange market intervention of 2000, gold sales during 2005-09 and the gradual rebalancing in favour of the yen portfolio. Important developments among the exchange rate effects were the long period of US dollar and Japanese yen depreciation, the strong rise in the gold price, and the strong Japanese yen appreciation in 2008. Although movements in the components of the foreign reserve portfolio changed the total value of the portfolio, the developments in assets occasionally offset each other, e.g. the gold price increase helped to offset the effect of the US dollar depreciation in the second half of the period. Furthermore, the use of revaluation accounts has been discussed. These proved useful by preventing temporary valuation gains, especially on the US dollar holdings, from being taken as profit and distributed. Concerning the own funds portfolio, a strong expansion has been observed, which was mainly driven by inflows from the investment of the bank's reserves. As a second driver, the liquidity operations in foreign currency, which the ECB undertook with non-euro area central banks during the 2007-
09 financial crisis, tripled the size of the ECB balance sheet during 2008. This resulted mainly from the fact that the amounts corresponding to the euro leg of US dollar swaps between the Federal Reserve and the ECB and between the ECB and the NCBs were not paid, but kept as liabilities and claims by the banks involved. A third driver was the ECB banknote issuance, which became a balance sheet item in 2002 . The banknote issuance followed the strong demand for euro banknotes, leading to a gradual expansion of the balance sheet over time.

2. The analysis of the profit and loss account showed that ECB income and expenses have been driven by the same three factors: seigniorage, financial market developments and portfolio management, and financial instability. These drivers help to explain the series of both annual profits and losses that the ECB made. Firstly, seigniorage, which depends on banknote demand and the marginal MRO rate, is an important component of ECB income. The strong demand for banknotes increased the potential income, but the dynamics in seigniorage to a large extent depended on the marginal MRO rate. Therefore, seigniorage contributed strongly to interest income towards the end of the period, reaching $€ 2,230$ million in 2008, but fell significantly in 2009. Secondly, financial market developments and portfolio management had an important impact on the financial result. Exchange rate developments led to write-downs on the foreign reserve assets, in particular during 2003-04 and 2007, by between $€ 2$ billion and $€ 4$ billion each time. The foreign exchange market intervention to support the euro exchange rate in 2000 and the gold sales during 2005-09 brought the biggest realised gains. Furthermore, investment earnings on the foreign reserve assets are an important income source, and hence interest rate developments are an important factor. The big share of US dollars in the portfolio and the, on average, higher interest rates made the US interest rates a dominant factor, albeit less so at the end of the period. As the ECB also pays euro area interest on its foreign reserves, the associated interest rate gap determines the net interest income from foreign 
reserves. The liability corresponds to the foreign reserves transferred by the NCBs. Thirdly, the financial crisis is identified as a factor that can weigh on the ECB financial result. The impact has been minor up to the end of 2009, but the final outcome will depend on the further course of the crisis and actions taken. On the one hand, a temporarily low seigniorage income as a result of low interest rates seems unavoidable. On the other hand, the crisis has triggered favourable revaluations (of exchange rates and bond prices) whose revaluation accounts act as a buffer outside the profit and loss account. The extra liquidity operations had as good as no impact on the financial result.

A number of financial buffers are in place to cover losses. Revaluation accounts act as a first buffer per asset by preventing unrealised gains from being taken as income. If these accounts do not suffice, then losses are offset against the risk provision and finally against the general reserve. Together, these buffers protected the ECB paid-up capital well, except in 2004 when the reserve and provision did not suffice and left a loss due to write-downs on the foreign reserve portfolio. The remaining loss was offset against Eurosystem monetary income, following a Governing Council decision. The latter also occurred in 1999 when no provisions were in place. Looking at the smoothing function of the reserve and provision, the provision was more important, partly because it can be built up faster. The buffers prevented a big loss in 2003, but had to absorb a smaller loss in 2004. In 2008, the risk provision reached its upper limit of $€ 4,020$ million for the first time and remained at this limit in 2009. The big write-downs of the past indicate, however, that this provision may be challenged again in the future, in particular if the dollar were to depreciate strongly.

3. The financial strength of the $\mathrm{ECB}$ was assessed based on the previous analysis and results found in the literature. The question was asked why the ECB needs financial strength and whether analysing accounts and maintaining financial buffers are only relevant at the microeconomic level. The answer is that the ECB, like other central banks, requires financial strength to credibly commit to a given nominal policy objective and contribute in a credible way to other potentially costly tasks of the Eurosystem, such as financial stability interventions. Three arguments were presented. First, a strong financial position helps the central bank to protect its independence from the government, a crucial component of its credibility. Second, it avoids the need or temptation to resort to printing money solely to support its financial position, an act that would conflict with the ECB's price stability objective. Third, it avoids doubts about its willingness to incur costs that would weigh on its financial position, e.g. to perform, together with the NCBs of the Eurosystem, its lender of last resort function in case of financial instability.

The ECB has remained financially strong throughout the 11-year period thanks to robust legislative provisions and the availability of financial buffers. Since the start of Monetary Union, legislative provisions on independence, capital, reserves, profit distribution and loss sharing have contributed to its financial strength by providing financial independence and transparency on the income allocated to the bank. The implementation of revaluation accounts and the building-up of the general reserve and special provision further protected the bank's capital to a great extent. The financial strength is also supported by seigniorage income, which still provides a reliable income source in the long run, even if the policy objective rules out the steering of seigniorage.

The financial strength of the ECB has mainly been tested by financial market developments. The unhedged foreign reserve positions are subject to exchange rate risk, which materialised with a number of write-downs. These can lead to negative financial results and call on the provision, particularly if they occur in a low interest rate environment, i.e. when other income is low. In general, although depreciations of foreign reserves are often temporary, they could push an already troubled financial position across the threshold where a recapitalisation is 
required. The same holds for the impact of the interest rate gap (between US and euro rates) which can drive the net interest income from foreign reserves down and depress the annual result. Although such developments weighed on the ECB's profit, they posed no real threat to the ECB's financial strength. Furthermore, other important risks to a central bank such as a persistent decrease in seigniorage appear less of a threat as banknote demand is strong. Finally, credit risk associated with Eurosystem credit operations remained with the NCBs. This risk materialised in late 2008 when five counterparties defaulted on refinancing operations undertaken by the Eurosystem. The Governing Council decided that the NCBs should establish their respective shares of a provision as a buffer against risks arising from collateral provided by these counterparties. 


\section{APPENDIX}

\section{DECOMPOSITION OF THE EURO EQUIVALENT OF FOREIGN RESERVE HOLDINGS INTO VOLUME AND PRICE COMPONENTS}

The decomposition is based on the total derivative of the euro equivalent. Let $p_{t}$ be the price and $q_{t}$ the volume at time $t$; it then holds for the euro equivalent $p_{t} q_{t}$ that:

$$
\frac{\partial p_{t} q_{t}}{\partial t} \approx p_{t} \frac{\partial q_{t}}{\partial t}+q_{t} \frac{\partial p_{t}}{\partial t}
$$

The first term corresponds to the volume effect, which in practice can be computed as $p_{t} \Delta q_{t}$. The second term is the price effect, $q_{t} \Delta p_{t}$. Together the effects approximate the change in the euro equivalent $\Delta\left(p_{t} q_{t}\right)$. The relationship does not hold exactly, because the direct effects that a volume change could have on the price and a price change could have on volume are not taken into account.

The differences between the left and right-hand side of the equation are typically small, and are not presented. The market intervention in 2000 was an obvious exception, because it aimed to affect the price by volume changes. By contrast, the spreading of gold sales across time aimed to avoid any significant effect on the price. The small differences between the left and right-hand side suggest that this has worked out for most gold sales.

\begin{tabular}{|c|c|c|c|c|c|c|c|c|c|c|c|c|}
\hline \multicolumn{13}{|l|}{ (EUR millions) } \\
\hline & 1998 & 1999 & 2000 & 2001 & 2002 & 2003 & 2004 & 2005 & 2006 & 2007 & 2008 & 2009 \\
\hline \multicolumn{13}{|l|}{ Assets } \\
\hline Gold and gold receivables & & 6,957 & 7,041 & 7,766 & 8,058 & 8,145 & 7,928 & 10,065 & 9,930 & 10,280 & 10,664 & 12,355 \\
\hline $\begin{array}{l}\text { Claims denominated } \\
\text { in foreign exchange }\end{array}$ & 343 & 44,518 & 41,300 & 44,871 & 40,364 & 31,605 & 29,655 & 34,142 & 32,502 & 32,890 & 63,837 & 38,750 \\
\hline Claims denominated & & & & & & & & & & & & \\
\hline $\begin{array}{l}\text { in EUR } \\
\text { Intra-Furosystem claims }\end{array}$ & 3,739 & 6,540 & $\begin{array}{r}4,654 \\
\end{array}$ & 4,815 & 83 & 475 & 88 & 13 & 4 & $\begin{array}{r}125 \\
\end{array}$ & 629 & $\begin{array}{r}2,182 \\
70873\end{array}$ \\
\hline $\begin{array}{l}\text { Intra-Eurosystem claims } \\
\text { Claims related } \\
\text { to the allocation }\end{array}$ & & & 13,081 & 9,697 & 34,150 & 39,499 & 43,512 & 50,364 & 53,805 & 71,372 & 295,117 & 70,873 \\
\hline of euro banknotes & & & & & 28,681 & 34,899 & 40,101 & 45,217 & 50,259 & 54,131 & 61,022 & 64,513 \\
\hline $\begin{array}{l}\text { Other claims within } \\
\text { the Eurosystem (net) }\end{array}$ & & & 13,081 & 9,697 & 5,468 & 4,600 & 3,411 & 5,147 & 3,546 & 17,241 & 234,096 & 6,360 \\
\hline Other assets & 59 & 1,468 & 1,264 & 911 & 7,512 & 6,331 & 7,393 & 8,160 & 9,525 & 11,376 & 13,656 & 13,838 \\
\hline Loss for the year & & 247 & & & & 477 & 1,636 & & & & & \\
\hline Total & 4,142 & 59,730 & 67,339 & 68,061 & 90,268 & 86,532 & 90,212 & 102,743 & 105,766 & 126,043 & 383,903 & 137,998 \\
\hline \multicolumn{13}{|l|}{ Liabilities } \\
\hline Banknotes in circulation & & & & & 28,681 & 34,899 & 40,101 & 45,217 & 50,259 & 54,131 & 61,022 & 64,513 \\
\hline $\begin{array}{l}\text { Liabilities denominated } \\
\text { in EUR }\end{array}$ & & 1,382 & 4,789 & 1,293 & 1,264 & 1,212 & 1,187 & 1,699 & 1,170 & 15,621 & 254,951 & 10,571 \\
\hline $\begin{array}{l}\text { Liabilities denominated } \\
\text { in foreign exchange }\end{array}$ & & 4,709 & 4,803 & 5,858 & 5,192 & 1,452 & 1,260 & 856 & 331 & 667 & 1,718 & 19 \\
\hline $\begin{array}{l}\text { Intra-Eurosystem liabilities } \\
\text { equivalent to the transfer of } \\
\text { foreign reserves }\end{array}$ & & 41,190 & 39,469 & 40,497 & 40,497 & 40,497 & 39,782 & 39,782 & 39,782 & 40,042 & 40,150 & 40,204 \\
\hline Other liabilities & 83 & 1,540 & 1,678 & 1,853 & 1,493 & 1,337 & 1,464 & 1,964 & 2,162 & 2,593 & 5,213 & 1,337 \\
\hline Provisions & 31 & 22 & 2,637 & 2,803 & 2,645 & 87 & 111 & 1,028 & 2,394 & 2,694 & 4,039 & 4,043 \\
\hline Revaluation accounts & 1 & 6,861 & 7,973 & 9,429 & 4,405 & 2,176 & 1,921 & 8,109 & 5,578 & 6,169 & 11,353 & 10,915 \\
\hline Capital and reserves & 4,000 & 4,027 & 4,000 & 4,506 & 4,870 & 4,870 & 4,385 & 4,089 & 4,089 & 4,127 & 4,137 & 4,142 \\
\hline Profit for the year & 28 & & 1,990 & 1,822 & 1,220 & & & 0 & 0 & 0 & 1,322 & 2,253 \\
\hline Total & 4,142 & 59,730 & 67,339 & 68,061 & 90,268 & 86,532 & 90,212 & 102,743 & 105,766 & 126,043 & 383,903 & 137,998 \\
\hline
\end{tabular}




\section{Table 2 ECB profit and loss account 1998-2009}

\begin{tabular}{|c|c|c|c|c|c|c|c|c|c|c|c|c|}
\hline \multicolumn{13}{|l|}{ (EUR millions) } \\
\hline & 1998 & 1999 & 2000 & 2001 & 2002 & 2003 & 2004 & 2005 & 2006 & 2007 & 2008 & 2009 \\
\hline \multicolumn{9}{|l|}{ Interest income on foreign } & 1,318 & 1,355 & 997 & 700 \\
\hline $\begin{array}{l}\text { Interest income arising from } \\
\text { the allocation of euro banknotes }\end{array}$ & & & & & & & & & & & & \\
\hline within the Eurosystem & & & & & 727 & 698 & 733 & 868 & 1,319 & 2,004 & 2,230 & 787 \\
\hline Other interest income & 0 & 3,357 & 4,657 & 2,271 & 1,965 & 1,450 & 1,457 & 1,794 & 2,762 & 4,380 & 8,431 & 5,608 \\
\hline Total interest income & 98 & 4,872 & 7,165 & 3,979 & 3,683 & 2,689 & 2,612 & 3,552 & 5,399 & 7,739 & 11,658 & 7,096 \\
\hline \multicolumn{13}{|l|}{$\begin{array}{l}\text { Remuneration of NCBs' claims } \\
\text { in respect of foreign reserves }\end{array}$} \\
\hline transferred & & -913 & $-1,375$ & $-1,509$ & $-1,141$ & -808 & -693 & -710 & -965 & $-1,357$ & $-1,400$ & -443 \\
\hline Other interest expense & -3 & $-3,205$ & $-4,375$ & $-1,698$ & $-1,547$ & $-1,167$ & $-1,229$ & $-1,572$ & $-2,462$ & $-3,962$ & $-7,877$ & $-5,106$ \\
\hline Total interest expense & -3 & $-4,118$ & $-5,750$ & $-3,207$ & $-2,688$ & $-1,975$ & $-1,922$ & $-2,282$ & $-3,427$ & $-5,319$ & $-9,277$ & $-5,549$ \\
\hline Net interest income & 95 & 754 & 1,414 & 771 & 995 & 715 & 690 & 1,270 & 1,972 & 2,421 & 2,381 & 1,547 \\
\hline $\begin{array}{l}\text { Realised gains/losses arising } \\
\text { from financial operations }\end{array}$ & 22 & -265 & 3,353 & 1,352 & 735 & 525 & 136 & 149 & 475 & 779 & 662 & 1,103 \\
\hline $\begin{array}{l}\text { Write-downs on financial assets } \\
\text { and positions }\end{array}$ & -22 & -605 & -1 & -109 & -277 & $-3,973$ & $-2,093$ & -97 & -718 & $-2,534$ & -3 & -37 \\
\hline $\begin{array}{l}\text { Transfer to provisions for foreign } \\
\text { exchange rate and price risks }\end{array}$ & & & $-2,600$ & 109 & 154 & 2,569 & 0 & -992 & $-1,379$ & -286 & $-1,339$ & 35 \\
\hline $\begin{array}{l}\text { Net result of financial } \\
\text { operations, write-downs } \\
\text { and risk provisions }\end{array}$ & 0 & -870 & 752 & 1352 & 612 & -879 & $-1,957$ & -940 & $-1,622$ & $-2,042$ & -679 & 1,099 \\
\hline $\begin{array}{l}\text { Other income and expenses } \\
\text { from fees and commissions }\end{array}$ & 0 & 1 & 2 & 2 & 4 & 3 & 6 & 18 & 11 & 7 & 8 & 8 \\
\hline Staff costs & -30 & -61 & -80 & -97 & -120 & -130 & -161 & -153 & -161 & -169 & -174 & -187 \\
\hline Administrative expenses & -30 & -61 & -83 & -185 & -134 & -154 & -176 & -158 & -166 & -185 & -183 & -186 \\
\hline $\begin{array}{l}\text { Depreciation of tangible } \\
\text { fixed assets }\end{array}$ & -8 & -10 & -14 & -20 & -18 & -30 & -34 & -32 & -29 & -26 & -23 & -21 \\
\hline Banknote production services & & & & & -118 & -2 & -3 & -4 & -5 & -5 & -7 & -6 \\
\hline Profit/loss for the year & 28 & -247 & 1,990 & 1,822 & 1,220 & -477 & $-1,636$ & 0 & 0 & 0 & 1,322 & 2,253 \\
\hline
\end{tabular}

Note: Figures as in corresponding annual report; totals may not add up due to rounding. 


\section{REFERENCES}

Barro, R.J. and D. Gordon (1983a), "A Positive Theory of Monetary Policy in a Natural Rate Model", Journal of Political Economy, 91(4), pp. 589-610.

Barro, R.J. and D. Gordon (1983b), "Rules, Discretion, and Reputation in a Model of Monetary Policy", Journal of Monetary Economics, 12, pp. 101-122.

Bindseil, U., A. Manzanares and B. Weller (2004), "The role of central bank capital revisited", ECB Working Paper No 392.

Cukierman, A. (2010), "Central Bank Finances and Independence - How Much Capital Should a CB Have?" in: S. Milton and P. Sinclair (eds.), The Capital Needs of Central Banks, Routledge International Studies in Money and Banking, forthcoming.

Dalton, J. and C. Dziobek (2005), "Central Bank Losses and Experiences in Selected Countries", IMF Working Paper No 72.

ECB (2007), “The EU arrangements for financial crisis management”, ECB Monthly Bulletin, February.

Frait, J. (2005), "Exchange Rate Appreciation and Negative Central Bank Capital: Is There a Problem?", remarks prepared for the Expert Forum on Central Bank Finances and Impact on Independence, Centre for Central Banking Studies, Bank of England, 31 August-2 September.

Goodhart, C.A.E. (2000), “Can Central Banking Survive the IT Revolution?”, International Finance, 3(2), pp. 189-209.

Hawkins, J. (2003), "Central Bank Balance Sheets and Fiscal Operations" in: Fiscal Issues and Central Banking in Emerging Economies, Bank for International Settlements, 20, pp. 71-83.

Ize, A. (2007), "Spending Seigniorage: Do Central Banks Have a Governance Problem?", IMF Staff Papers, 54, pp. 563-589.

Ize, A. and N. Oulidi (2009), “Why Do Central Banks Go Weak?”, IMF Working Paper No 13.

Martínez-Resano, J.R. (2004), “Central Bank Financial Independence”, Banco de España Occasional Paper No 401.

Sargent, T. and N. Wallace (1981), "Some Unpleasant Monetarist Arithmetic", Federal Reserve Bank of Minneapolis Quarterly Review, 5, pp. 291-307.

Stella, P. (2005), "Central Bank Financial Strength, Transparency, and Political Credibility", IMF Staff Papers, 52(2), pp. 335-365.

Stella, P. (2008), "Central Bank Financial Strength, Policy Constraints and Inflation”, IMF Working Paper No 49.

Stella, P. and Å. Lonnberg (2008), "Issues in Central Bank Finance and Independence”, Federal Reserve Bank of Atlanta Working Paper No 13. 


\section{EUROPEAN CENTRAL BANK}

100 "Survey data on household finance and consumption: research summary and policy use" by the Eurosystem Household Finance and Consumption Network, January 2009.

101 "Housing finance in the euro area" by a Task Force of the Monetary Policy Committee of the European System of Central Banks, March 2009.

102 "Domestic financial development in emerging economies: evidence and implications" by E. Dorrucci, A. Meyer-Cirkel and D. Santabárbara, April 2009.

103 "Transnational governance in global finance: the principles for stable capital flows and fair debt restructuring in emerging markets" by R. Ritter, April 2009.

104 "Fiscal policy challenges in oil-exporting countries - a review of key issues" by M. Sturm, F. Gurtner and J. Gonzalez Alegre, June 2009.

105 "Flow-of-funds analysis at the ECB - framework and applications" by L. Bê Duc and G. Le Breton, August 2009.

106 "Monetary policy strategy in a global environment" by P. Moutot and G. Vitale, August 2009.

107 "The collateral frameworks of the Eurosystem, the Federal Reserve System and the Bank of England and the financial market turmoil" by S. Cheun, I. von Köppen-Mertes and B.Weller, December 2009.

108 "Trade consistency in the context of the Eurosystem projection exercises - an overview" by K. Hubrich and T. Karlsson, March 2010.

109 "Euro area fiscal policies and the crisis" by editor Ad van Riet, April 2010.

110 "Protectionist responses to the crisis: global trends and implications" by M. Bussière, E. Pérez-Barreiro, R. Straub and D. Taglioni, April 2010.

111 "Main drivers of the ECB financial accounts and ECB financial strength over the first 11 years" by O. Vergote, W. Studener, I. Efthymiadis and N. Merriman, May 2010. 



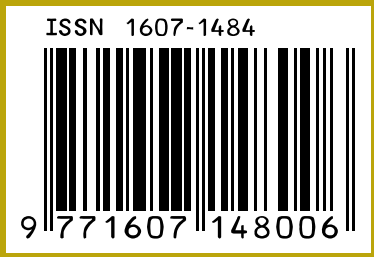

